\title{
Water exchange in lanthanide complexes for MRI applications. Lessons learned over the last 25 years
}

\author{
$\underline{\text { Peter Caravan }}^{\mathrm{b}}, \underline{\text { David Esteban-Gómez }}^{\mathrm{a}}, \underline{\text { Aurora Rodríguez-Rodríguez }}^{\mathrm{a}}$ and $\underline{\text { Carlos Platas-Iglesias }}^{\mathrm{ab}^{\mathrm{b}}}$ \\ ${ }^{a}$ Centro de Investigacións Científicas Avanzadas (CICA) and Departamento de Química, Universidade da Coruña, \\ Campus da Zapateira-Rúa da Fraga 10, 15008 A Coruña, Spain \\ ${ }^{\mathrm{b}}$ The Institute for Innovation in Imaging and the A. A. Martinos Center for Biomedical Imaging, Massachusetts \\ General Hospital, Harvard Medical School, 149 13th Street, Suite 2301, Charlestown, Massachusetts 02129, USA
}

Dalton Transactions, volume 48, issue 30, pages 11161-11180, 14 August 2019

Submitted 10 May 2019, accepted 18 June 2019, first published 19 June 2019

\section{How to cite:}

P. Caravan, D. Esteban-Gómez, A. Rodríguez-Rodríguez and C. Platas-Iglesias, Water exchange in lanthanide complexes for MRI applications. Lessons learned over the last 25 years, Dalt. Trans., 2019, 48, 11161-1118. DOI: 10.1039/C9DT01948K.

\begin{abstract}
The water exchange rates of water molecules coordinated to the metal ion in lanthanide complexes have been profusely investigated during the last 25 years, especially in the case of $\mathrm{Gd}^{3+}$ and $\mathrm{Eu}^{3+}$ complexes. This is mainly related to the important application of some $\mathrm{Gd}^{3+}$ complexes as contrast agents in magnetic resonance imaging (MRI), and the intensive investigation of $\mathrm{Eu}^{3+}$ complexes as contrast agent candidates providing contrast through the chemical exchange saturation transfer mechanism (CEST). Both applications require a fine tunning of the exchange rate of the coordinated water molecule to yield optimal response. Herein we review the progress made in this field to control water exchange in a rational way through ligand design, providing relationships between the observed trends, the structures of the complexes and the mechanisms responsible for the water exchange reaction.
\end{abstract}

\section{Introduction}

Water and other solvent exchange reactions are among the most fundamental and well studied reactions of metal complexes. ${ }^{1}$ They are of paramount importance for the understanding of the reactivity of metal ions in chemical, biological and geochemical systems, ${ }^{2}$ as well as to investigate the nature of the interaction between metal ions and solvent molecules. The exchange rates of coordinated water molecules of aquated ions were found to vary dramatically depending on the metal and oxidation state. For instance, the lowest water exchange rate among the aquated ions was reported for the $\left[\operatorname{Ir}\left(\mathrm{H}_{2} \mathrm{O}\right)_{6}\right]^{3+}$ complex, whose water molecule remains in the inner coordination sphere with an average lifetime of 300 years, ${ }^{3}$ whereas the mean residence time of a coordinated water molecule in $\left[\mathrm{Eu}\left(\mathrm{H}_{2} \mathrm{O}\right)_{7}\right]^{2+}$ is 20 orders of magnitude lower $(200 \mathrm{ps}){ }^{4}$ The exchange rates of inner-sphere water molecules are often determined by using variable temperature ${ }^{17} \mathrm{O}$ NMR measurements, which provide the exchange rates and the associated activation parameters. ${ }^{5}$ Mechanistic insight can be obtained from the sign of the entropy of activation $\left(\Delta S^{*}\right)$, which is generally negative for associatively activated mechanisms and positive for reactions following a dissociative

*carlos.platas.iglesias@udc.es 
mechanism. However, the nature of the mechanism is more reliably assessed by using variable pressure measurements, as the sign of the activation volume $\left(\Delta V^{*}\right)$ provides a more straightforward assignment of the reaction mechanism. ${ }^{6}$ If the exchange rate slows down with increasing pressure this indicates a dissociative process that is characterized by a positive $\Delta V^{*}$ value, while an associative water exchange reaction will see the rate increase with increasing pressure. The limiting values for activation volumes were estimated to be $\pm 13.5 \mathrm{~cm}^{3} \mathrm{~mol}^{-1}$, and thus associative or dissociated mechanisms are characterized by $\Delta V^{\ddagger}$ values close to $\pm 13.5 \mathrm{~cm}^{3} \mathrm{~mol}^{-1}{ }^{7}$ An interchange mechanism is expected to present $\Delta V^{*} \approx 0$, while associative or dissociative interchange reactions present $\Delta V^{*}$ values intermediate between those characterizing the limiting mechanisms and zero (Fig. 1).

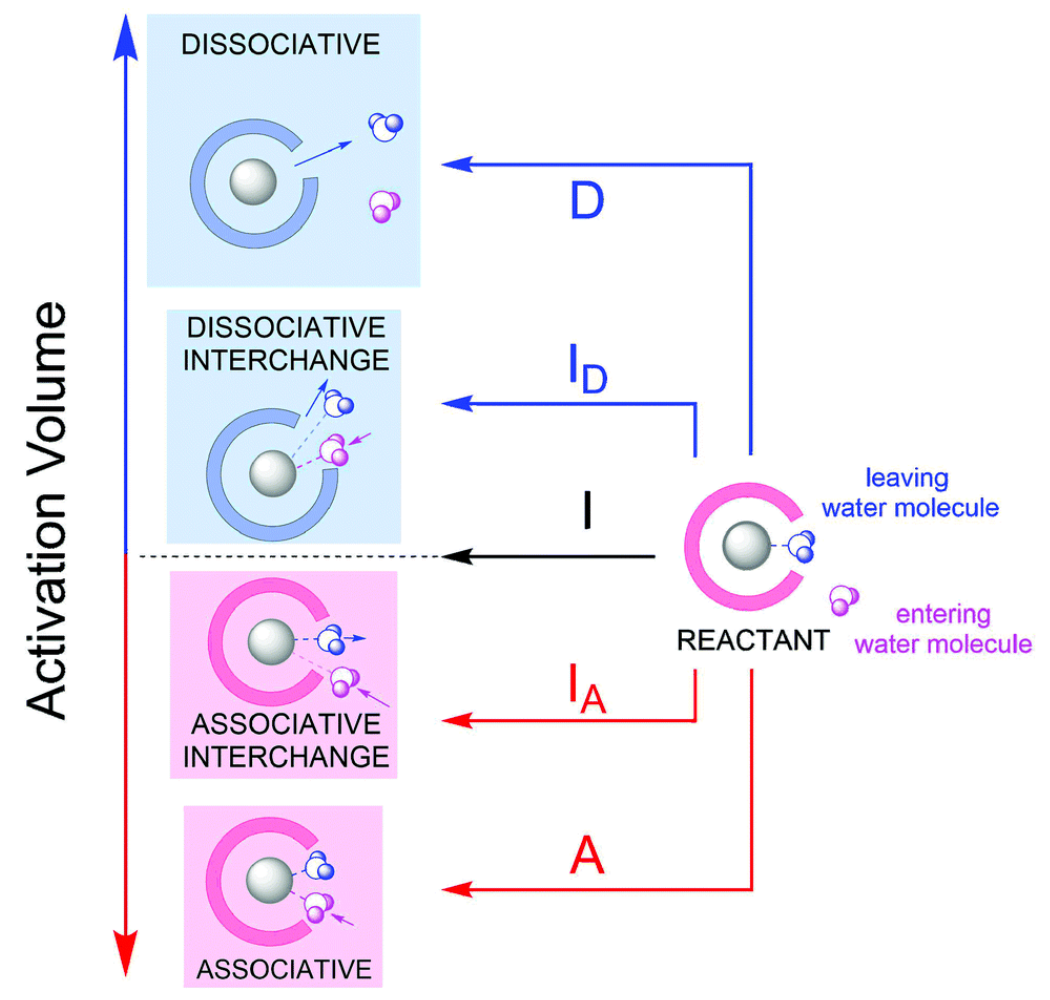

Fig. 1. Schematic representation of the water exchange mechanisms in a metal complex.

Water exchange in the aquated lanthanide $\left(\mathrm{Ln}^{3+}\right)$ ions were investigated across the series by Merbach $e t$ al. in the late 1980s and early 1990s. ${ }^{8}$ These studies evidenced a changeover in the reaction mechanism from dissociative to associative as the ionic radius of the $\mathrm{Ln}^{3+}$ decreased, an effect explained by a change in the coordination number across the series from nine for the largest $\mathrm{Ln}^{3+}$ ions to eight. The interest in the water exchange reaction of $\mathrm{Ln}^{3+}$ complexes increased after the introduction of some $\mathrm{Gd}^{3+}$ complexes as contrast agents in magnetic resonance imaging (MRI). ${ }^{9}$ These agents take advantage of the paramagnetism of the $\mathrm{Gd}^{3+}$ ion to shorten the longitudinal $\left(T_{1}\right)$ and/or transverse $\left(T_{2}\right)$ relaxation times of water molecules in their surroundings. ${ }^{10}$ Gadolinium-based contrast agents are ternary complexes with $\mathrm{Gd}^{3+}$ coordinated by a multidentate ligand and at least one water ligand that is in exchange with the surrounding water molecules. The response of the agent is generally measured in relaxivity units, defined as the relaxation rate enhancement effect induced by the paramagnetic probe normalized to probe concentration (units $\mathrm{mM}^{-1} \mathrm{~s}^{-1}$ ). Relaxivity is determined by several parameters, among which water exchange is a critical one, especially for slow tumbling complexes and particularly at the low magnetic fields used in traditional MRI scanners ( 0.2 to 
$1.5 \mathrm{~T}) .{ }^{11}$ Optimal water exchange rates at high magnetic fields $(>3 \mathrm{~T})$ present a broader range, but still suboptimal water exchange may limit relaxivity at high fields. ${ }^{12}$

Besides the traditional $\mathrm{Gd}^{3+}$-based contrast agents, intense research efforts have been devoted to develop contrast agents based on other $\mathrm{Ln}^{3+}$ ions and the Chemical Exchange Saturation Transfer (CEST) mechanism. ${ }^{13}$ These complexes contain a pool of protons involved in slow-to-intermediate exchange with bulk water, so that saturation at the resonance frequency of these protons results in a decrease of the intensity of bulk water signal through magnetization transfer. The exchangeable protons in $\mathrm{Ln}^{3+}$ CEST agents may be provided for instance by amide, ${ }^{14}$ hydroxyl, ${ }^{15}$ or amine ${ }^{16}$ groups present in the ligand structure, or alternatively by coordinated water molecules showing slow exchange with bulk water. ${ }^{17}$

The important application of $\mathrm{Ln}^{3+}$ complexes as MRI contrast agents and the critical role of water exchange in their response as either $T_{1}$ or CEST agents prompted many groups to optimize the ligand design to obtain water exchange rates in the desired range. The huge amount of data accumulated over the last two decades afforded different strategies to modulate water exchange in $\mathrm{Ln}^{3+}$ complexes. ${ }^{9 \mathrm{~b}} \mathrm{In}$ spite of the importance of controlling $k_{\mathrm{ex}}$ to obtain more efficient MRI contrast agents, this issue has been widely overlooked in the literature, with only a few reviews focussing on this specific problem. ${ }^{11,18}$ The purpose of this review is to delineate the main factors that impact water exchange in $\mathrm{Ln}^{3+}$ complexes relevant to MRI, providing selected examples that illustrate the relation between the observed exchange rates and the structure of the complex at the molecular level.

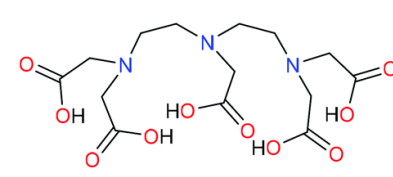

DTPA

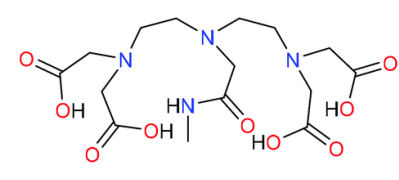

DTPA-cMA

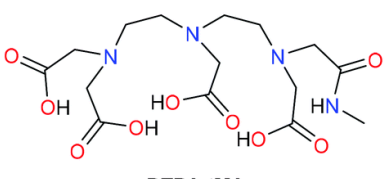

DTPA-tMA
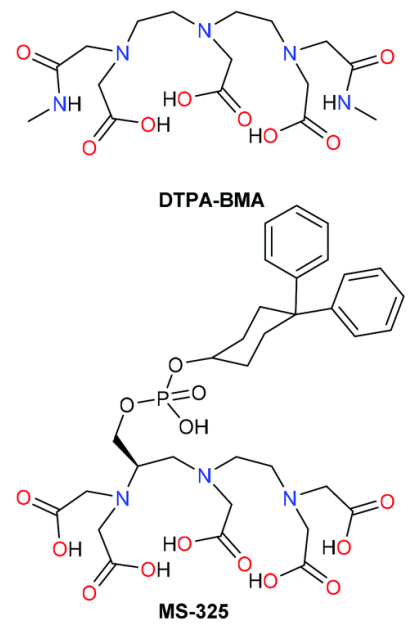

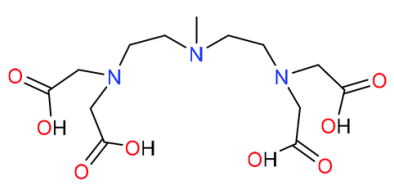

DTTA-Me

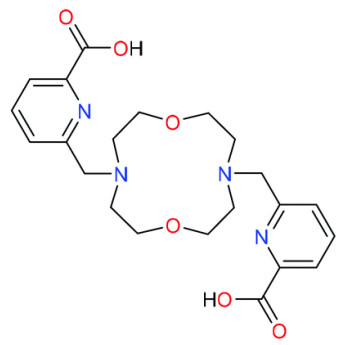

BP12C4

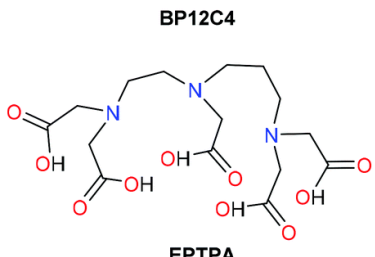

EPTPA

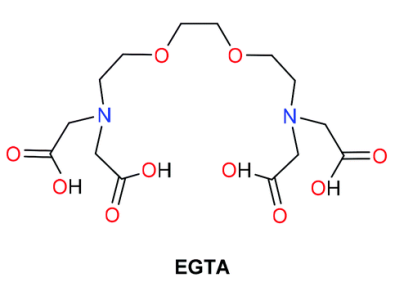<smiles>O=C(O)CN1CCN(CC(=O)O)CCN(CC(=O)O)CCN(Cc2ccc([N+](=O)[O-])cc2)CCN(CC(=O)O)CC1</smiles><smiles>NC1C(O)C(N)C2CC1C(N)C2O</smiles><smiles>O=C(O)CN1CCN(CC(=O)O)CCN(CC(=O)O)CCN(CC(=O)O)CC1</smiles><smiles>C[C@H](C(=O)O)[C@@H](C)N1CCN(CC(=O)O)CCN(CC(=O)O)CCN(CC(=O)O)CC1</smiles><smiles>O=C(O)CN1CCCN(CC(=O)O)CCN(CC(=O)O)CCCN(CC(=O)O)CC1</smiles>

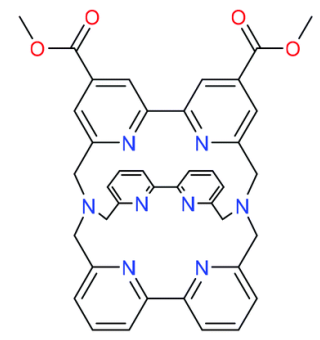

bipy $_{2}$-bipy-4,4'-CoOMe

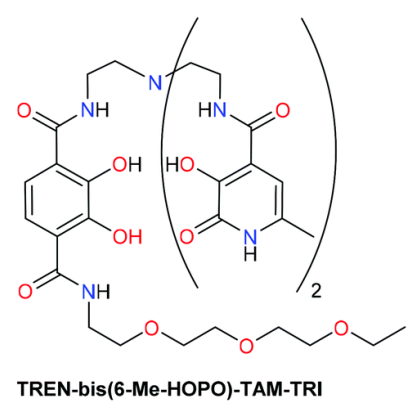

Fig. 2. Chelators for the $\mathrm{Gd}^{3+}$ complexes described in Table 1 and in the text. 
Table 1. Selected rate constants and activation parameters reported for $\mathrm{Gd}^{3+}$ complexes.

\begin{tabular}{|c|c|c|c|c|c|}
\hline Complex & $k_{\mathrm{ex}}^{298} / 10^{6} \mathrm{~s}^{-1}$ & $\Delta H^{*} / \mathrm{kJ} \mathrm{mol}^{-1}$ & $\Delta S^{\ddagger} / \mathrm{J} \mathrm{mol}^{-1} \mathrm{~K}^{-1}$ & $\Delta V^{\ddagger} / \mathrm{cm}^{3} \mathrm{~mol}^{-1}$ & Ref. \\
\hline$\left[\mathrm{Gd}\left(\mathrm{H}_{2} \mathrm{O}\right)_{8}\right]^{3+}$ & 830 & 14.9 & -24.1 & -3.3 & 25 \\
\hline$\left[\mathrm{Gd}(\mathrm{DTPA})\left(\mathrm{H}_{2} \mathrm{O}\right)\right]^{2-}$ & 3.3 & 51.6 & +53 & +12.5 & 21 \\
\hline$\left[\mathrm{Gd}(\mathrm{DTPA}-\mathrm{cMA})\left(\mathrm{H}_{2} \mathrm{O}\right)\right]^{-}$ & 1.9 & 50.6 & +40.2 & +10.6 & 35 \\
\hline$\left[\mathrm{Gd}(\mathrm{DTPA}-\mathrm{tMA})\left(\mathrm{H}_{2} \mathrm{O}\right)\right]^{-}$ & 1.3 & 48.6 & +35.7 & +12.7 & 35 \\
\hline$\left[\mathrm{Gd}(\mathrm{DTPA}-\mathrm{BMA})\left(\mathrm{H}_{2} \mathrm{O}\right)\right]$ & 0.43 & 46.6 & +18.9 & +7.3 & 21 \\
\hline$\left[\mathrm{Gd}(\mathrm{DTTA}-\mathrm{Me})\left(\mathrm{H}_{2} \mathrm{O}\right)_{2}\right]^{-}$ & 24.6 & 50 & +64 & +8 & 23 \\
\hline$\left[\mathrm{Gd}(\mathrm{DTTA}-\mathrm{Me}) \mathrm{F}\left(\mathrm{H}_{2} \mathrm{O}\right)\right]^{2-}$ & 177 & 42 & +53 & +15 & 23 \\
\hline$\left[\mathrm{Gd}(\mathrm{EGTA})\left(\mathrm{H}_{2} \mathrm{O}\right)\right]^{-}$ & 31 & 42.7 & +42 & +10.5 & 24 \\
\hline$\left[\mathrm{Gd}(\mathrm{EPTPA})\left(\mathrm{H}_{2} \mathrm{O}\right)\right]^{2-}$ & 330 & 27.7 & +11 & +6.6 & 57 \\
\hline$\left[\mathrm{Gd}(\mathrm{DOTA})\left(\mathrm{H}_{2} \mathrm{O}\right)\right]^{-a}$ & 4.1 & 49.8 & +48.5 & +10.5 & 21 \\
\hline$\left[\mathrm{Gd}(\mathrm{TRITA})\left(\mathrm{H}_{2} \mathrm{O}\right)\right]^{-}$ & 270 & 17.5 & -24 & -1.5 & 55 and 57 \\
\hline$\left[\mathrm{Gd}\left(\mathrm{DO} 3 \mathrm{AM}-b z-\mathrm{NO}_{2}\right)\left(\mathrm{H}_{2} \mathrm{O}\right)\right]$ & 1.6 & 40.9 & +11 & +7.7 & 36 \\
\hline$\left[\mathrm{Gd} 3\left(\mathrm{H}_{-3} \mathrm{TACI}\right)_{2}\left(\mathrm{H}_{2} \mathrm{O}\right)_{6}\right]^{3+}$ & 11 & 59.8 & -89 & -12.7 & 28 \\
\hline$\left[\mathrm{Gd}\left(\text { bipy }_{2}-4,4^{\prime}-\mathrm{COOMe}\right)\left(\mathrm{H}_{2} \mathrm{O}\right)_{3}\right]^{3+}$ & 0.97 & 31.3 & -25.6 & -2.5 & 29 \\
\hline [Gd(TREN-bis(6-Me-HOPO)-TAM-TRI) $\left.\left(\mathrm{H}_{2} \mathrm{O}\right)_{2}\right]$ & 53 & 25.9 & $b$ & -5 & 26 \\
\hline
\end{tabular}

${ }^{a}$ The different contributions of SAP and TSAP isomers were not considered. ${ }^{b}$ Not reported.

\section{Water exchange mechanisms in $\mathrm{Gd}^{3+}$ complexes}

The most common coordination numbers of $\mathrm{Gd}^{3+}$ complexes in aqueous solution are eight and nine, ${ }^{19}$ though several examples of ten-coordinated complexes with decadentate ligands have also been reported. ${ }^{20}$ Thus, the general trend observed is that eight-coordinate $\mathrm{Gd}^{3+}$ complexes present associatively activated water exchange reactions, while dissociative pathways are generally followed by nine-coordinate complexes. Complexes belonging to the latter group are for instance the classical DOTA, ${ }^{21}$ DTPA $^{21}$ and DTPAbisamide ${ }^{21,22} \mathrm{Gd}^{3+}$ complexes currently used as commercial MRI contrast agents, as well as the structurally related DTTA-Me $\mathrm{Me}^{23}$ and EGTA ${ }^{24}$ complexes (Fig. 2). The $\mathrm{Gd}^{3+}$ ion in these complexes is directly coordinated to eight donor atoms of the polyaminopolycarboxylate ligand (seven for DTTA-Me), leaving one coordination position available for a water molecule (two for DTTA-Me). The water exchange mechanism was assessed by determining the corresponding $\Delta V^{\ddagger}$ values, which are all positive (Table 1). The activation parameters are characterized by rather high activation enthalpies $\left(\Delta H^{\ddagger}\right)$ and positive $\Delta S^{\ddagger}$ values, as would be expected. The large $\Delta H^{\ddagger}$ values are likely related to the energy cost required to break the bond between the metal ion and the leaving water molecule to reach the eight-coordinate transition state.

There are only a few reported examples of ligand types that form $\mathrm{Gd}^{3+}$ complexes with associatively activated water exchange mechanisms, including the aqua ion $\left[\mathrm{Gd}\left(\mathrm{H}_{2} \mathrm{O}\right)_{8}\right]^{3+25}$. The eight-coordinate complexes of the HOPO family were found to present associatively activated water exchange reactions, as confirmed by the activation volume determined for [Gd(TREN-bis(6-Me-HOPO)-TAM-TRI $\left.)\left(\mathrm{H}_{2} \mathrm{O}\right)_{2}\right]\left(\Delta V^{*}=\right.$ $\left.-5 \mathrm{~cm}^{3} \mathrm{~mol}^{-1}\right) .{ }^{26}$ Presumably other members of the HOPO family present associatively activated mechanisms as well, although $\Delta V^{*}$ values have not been reported. ${ }^{27}$ The eight-coordinate trinuclear $\left[\mathrm{Gd}_{3}\left(\mathrm{H}_{-3} \mathrm{TACI}\right)_{2}\left(\mathrm{H}_{2} \mathrm{O}\right)_{6}\right]^{3+}$ complex was also found to display an associatively activated water exchange process $\left(\Delta V^{*}=-12.7 \mathrm{~cm}^{3} \mathrm{~mol}^{-1}\right){ }^{28}$ Interestingly, the nine-coordinate $\left[\mathrm{Gd}\left(\text { bipy }_{2}-4,4^{\prime}-\mathrm{COOMe}\right)\left(\mathrm{H}_{2} \mathrm{O}\right)_{3}\right]^{3+}$ complex presents an associative interchange mechanisms $\left(\Delta V^{\ddagger}=-2.5 \mathrm{~cm}^{3} \mathrm{~mol}^{-1}\right)$, presumably through the formation of a ten-coordinate transition state. ${ }^{29} \mathrm{~A}$ similar situation was postulated for the $\left[\mathrm{Gd}(\mathrm{BP} 12 \mathrm{C} 4)\left(\mathrm{H}_{2} \mathrm{O}\right)_{q}\right]^{+}$complex ${ }^{30}$ which presents an equilibrium in solution involving nine- $(q=1)$ and tencoordinate $(q=2)$ species. ${ }^{31}$ The large negative value of the activation entropy $\left(\Delta S^{\sharp}=-35 \mathrm{~J} \mathrm{~mol}^{-1} \mathrm{~K}^{-1}\right)$ 
suggested that the water exchange presents associative character, being dominated by the nine-coordinate complex with formation of a ten-coordinate transition state. It is important to note that the water exchange rates are not directly linked to the type of mechanism responsible for the water exchange reaction, as both fast and slow exchange reactions were observed for complexes undergoing both associatively and dissociatively activated mechanisms. For instance, the water exchange reported for [Gd(TREN-bis(6-MeHOPO)-TAM-TRI $\left.)\left(\mathrm{H}_{2} \mathrm{O}\right)_{2}\right]$ is about 55 times faster than that of $\left[\mathrm{Gd}\left(\mathrm{bipy}_{2}-4,4^{\prime}-\mathrm{COOMe}\right)\left(\mathrm{H}_{2} \mathrm{O}\right)_{3}\right]^{3+}$, in spite of the similar activation volumes (Table 1).

\section{Water exchange rates in $\mathrm{Gd}^{3+}\left(\right.$ and $\left.\mathrm{Eu}^{3+}\right)$ complexes}

The water exchange rates determined so far for $\mathrm{Gd}^{3+}$ complexes cover a range of about four orders of magnitude, with the highest water exchange rate being that of the $\left[\mathrm{Gd}\left(\mathrm{H}_{2} \mathrm{O}\right)_{8}\right]^{3+}$ ion $\left(k_{\mathrm{ex}}^{298}=830 \times\right.$ $\left.10^{6} \mathrm{~s}^{-1}\right),{ }^{25}$ and the lowest the one reported for DOTA-tetraamide derivatives $\left(k_{\mathrm{ex}}^{298}=0.053-0.125 \times\right.$ $\left.10^{6} \mathrm{~s}^{-1}\right){ }^{32}$ Even lower water exchange rates were reported for certain $\mathrm{Eu}^{3+}$ DOTA-tetraamide complexes (as low as $\left.0.00136 \times 10^{6} \mathrm{~s}^{-1}\right) .{ }^{33}$ Several structural factors were found to be important in the modulation of water exchange rates. In the following sections we will show how rational ligand design can be successfully employed to modulate water exchange, focusing on both $\mathrm{Gd}^{3+}$ and $\mathrm{Eu}^{3+}$ complexes. These two metal ions present very similar ionic radii and thus chemical properties. For instance, the hydration numbers of $\mathrm{Gd}^{3+}$ complexes are often estimated from spectroscopic measurements performed for the $\mathrm{Eu}^{3+}$ analogues, generally by using luminescence lifetime measurements in $\mathrm{H}_{2} \mathrm{O}$ and $\mathrm{D}_{2} \mathrm{O}$ solutions of the complex. ${ }^{34}$ The water exchange rates reported for $\mathrm{Gd}^{3+}$ complexes were generally determined by using ${ }^{17} \mathrm{O}$ NMR measurements, while in the case of $\mathrm{Eu}^{3+}$, high-resolution ${ }^{1} \mathrm{H}$ NMR and CEST spectra are generally the tools of choice.

\section{Effect of complex charge}

Complex charge was one of the first factors that were noticed to affect significantly water exchange rates by comparing kinetic data obtained for structurally related complexes. For instance, the water exchange rate determined for $\left[\mathrm{Gd}(\mathrm{DTPA})\left(\mathrm{H}_{2} \mathrm{O}\right)\right]^{2-}\left(k_{\mathrm{ex}}^{298}=3.3 \times 10^{6} \mathrm{~s}^{-1}\right)^{21}$ was found to be significantly faster than those of $\left[\mathrm{Gd}(\mathrm{DTPA}-\mathrm{cMA})\left(\mathrm{H}_{2} \mathrm{O}\right)\right]^{-}\left(k_{\mathrm{ex}}^{298}=1.9 \times 10^{6} \mathrm{~s}^{-1}\right)$ and $\left[\mathrm{Gd}(\mathrm{DTPA}-\mathrm{tMA})\left(\mathrm{H}_{2} \mathrm{O}\right)\right]^{-}\left(k_{\mathrm{ex}}^{298}=1.3 \times 10^{6} \mathrm{~s}^{-1}\right),{ }^{35}$ which in turn are higher than that of the charge neutral $\left[\mathrm{Gd}(\mathrm{DTPA}-\mathrm{BMA})\left(\mathrm{H}_{2} \mathrm{O}\right)\right]$ complex $\left(k_{\mathrm{ex}}^{298}=0.43 \times\right.$ $\left.10^{6} \mathrm{~s}^{-1}\right){ }^{21} \mathrm{~A}$ similar situation is observed for DOTA derivatives by comparing the exchange rates of $\left[\mathrm{Gd}(\mathrm{DOTA})\left(\mathrm{H}_{2} \mathrm{O}\right)\right]^{-}\left(k_{\mathrm{ex}}^{298}=4.1 \times 10^{6} \mathrm{~s}^{-1}\right)^{21}$ and the mono-amide derivative [Gd(DO3AM- $\left.b z-\mathrm{NO}_{2}\right)\left(\mathrm{H}_{2} \mathrm{O}\right)$ ] $\left(k_{\mathrm{ex}}^{298}=1.6 \times 10^{6} \mathrm{~s}^{-1}\right) \cdot{ }^{36}$ However, these complexes are present in solution as a mixture of diastereoisomers that show different water exchange rates (see below). Thus, a more appropriate comparison is probably given by the [GdL1] and [GdL2] $]^{+}$complexes (Fig. 3), which were found to exist in solution exclusively as the capped square antiprismatic (SAP) isomers. Again, a notable decrease of the water exchange is observed upon increasing the positive charge of the complex from $k_{\mathrm{ex}}^{298}=1.52 \times 10^{6} \mathrm{~s}^{-1}$ to $k_{\mathrm{ex}}^{298}=0.73 \times 10^{6} \mathrm{~s}^{-1} \cdot{ }^{37} \mathrm{~A}$ very important increase in the water exchange rate was also observed upon replacing one of the coordinated water molecules of $\left[\mathrm{Gd}(\mathrm{DTTA}-\mathrm{Me})\left(\mathrm{H}_{2} \mathrm{O}\right)_{2}\right]^{-}$by a fluoride ligand (Table 1). ${ }^{23}$ The explanation of these trends is straightforward: an increase in positive charge results in a stronger electrostatic interaction between the metal ion and the oxygen atom of the inner-sphere water molecule. As a result, the energy cost required to break the $\mathrm{Gd}-\mathrm{O}_{\text {water }}$ bond and reach the eight-coordinate transition state increases, slowing down water exchange. Computational evidence relating the strength of the $\mathrm{Gd}-\mathrm{O}_{\text {water }}$ bonds and the observed water exchange rates was provided recently with DFT studies. ${ }^{38}$ 
<smiles>CC(O)CN1CCN(CC(=O)O)CCN(CC(=O)O)CCN(CC(=O)O)CC1</smiles><smiles>O=C(O)CN1CCN(CC(=O)O)CCN(CC(=O)Nc2cc(C(F)(F)F)cc(C(F)(F)F)c2)CCN(CC(=O)O)CC1</smiles><smiles>CC(C(=O)O)N1CCN(C(C)C(=O)O)CCN(C(C)C(=O)O)CCN(C(C)C(=O)O)CC1</smiles><smiles>O=C(O)CN1CCN(CC(=O)O)CCN(CC(=O)Nc2ccc(C(F)(F)F)cc2)CCN(CC(=O)Nc2ccc(C(F)(F)F)cc2)CC1</smiles>

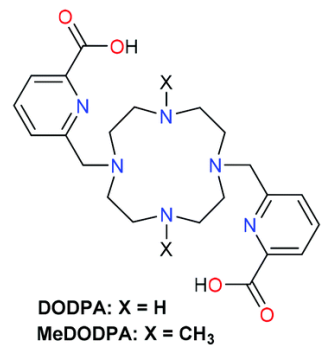<smiles>NC(=O)CN1CCN(CC(N)=O)CCN(CC(N)=O)CN(CC(N)=O)CC1</smiles><smiles>CNC(=O)CN1CCN(CC(=O)NC)CCN(CC(=O)NC)CCN(CC(=O)NC)CC1</smiles><smiles>CC(C(N)=O)C(C)N1CCN(C(C)C(N)=O)CCN(C(C)C(N)=O)CCN(C(C)C(N)=O)CC1</smiles><smiles>O=C(O)CNC(=O)CN1CCN(CC(=O)NCC(=O)O)CCN(CC(=O)NCC(=O)O)CCN(CC(=O)NCC(=O)O)CC1</smiles>

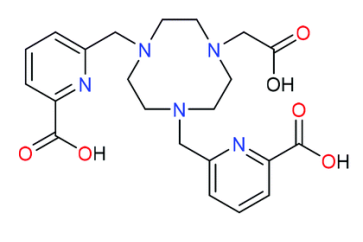

BPATCN

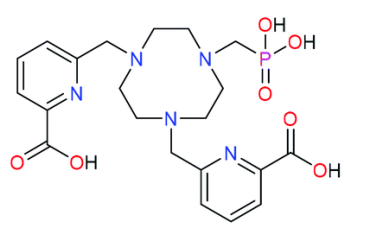

PBPATCN

Fig. 3. Macrocyclic ligands used for $\mathrm{Gd}^{3+}$ and $\mathrm{Eu}^{3+}$ complexation.

\section{The role of SAP and TSAP isomers}

It is well known that $\mathrm{Ln}^{3+}$ DOTA-like complexes exist in solution as an equilibrium of two diastereoisomeric forms, labelled initially as $\mathbf{m}$ (minor) and $\mathbf{M}$ (major) after their relative populations determined by ${ }^{1} \mathrm{H}$ NMR. ${ }^{39}$ These isomers differ by the layout of their acetate pendant arms or the conformation of the macrocyclic fragment: the $\mathbf{M}$ isomer has a square antiprismatic geometry (SAP), whereas the $\mathbf{m}$ isomer presents a twisted square antiprismatic geometry (TSAP). The stereochemistry of these complexes was described in detail in several articles and reviews. ${ }^{40}$

Water exchange of the two isomers of $\left[\operatorname{Eu}(\text { DOTAM })\left(\mathrm{H}_{2} \mathrm{O}\right)\right]^{3+}$ was first investigated in acetonitrile solution, as the ${ }^{1} \mathrm{H}$ NMR signal of the coordinated water molecules could be directly detected. ${ }^{41}$ Subsequent studies showed that the NMR signals of the coordinated water molecules in $\mathrm{Eu}^{3+}$ complexes of DOTAM, DTMA, DOTMAM (Fig. 3) and other DOTA-tetraamide derivatives could be directly observed also in pure water. ${ }^{42-}$ ${ }^{44}$ These exciting results allowed Sherry et al. to propose $\mathrm{Eu}^{3+}$-tetraamide complexes as potential MRI CEST agents ${ }^{45}$ which opened a new entire field of research in MRI. ${ }^{46}$ The kinetic data obtained for the two isomers of selected $\mathrm{Eu}^{3+}$-tetraamide complexes are compiled in Table 2. The $k_{\mathrm{ex}}^{298}$ values indicate that water exchange in the TSAP isomer is $40-50$ times faster than in the SAP one. This has been correlated to a weaker interaction between the coordinated water molecule and the metal ion in the TSAP isomer, originating by a higher steric strain at the $\mathrm{O}_{4}$ plane. ${ }^{47,48}$ The activation parameters reported in the literature are characteristic of dissociatively activated processes, with positive $\Delta S^{\ddagger}$ and $\Delta V^{*}$ values. 
Table 2. Rate constants and activation parameters reported for selected $\mathrm{Eu}^{3+}$ and $\mathrm{Gd}^{3+}$ DOTA-tetraamide derivatives.

\begin{tabular}{|c|c|c|c|c|c|c|}
\hline Complex & Isomer & $k_{\mathrm{ex}}^{298} / 10^{3} \mathrm{~s}^{-1}$ & $\Delta H^{\ddagger} / \mathbf{k J} \mathrm{mol}^{-1}$ & $\Delta S^{\ddagger} / \mathrm{J} \mathrm{mol}^{-1} \mathrm{~K}^{-1}$ & $\Delta V^{*} / \mathrm{cm}^{3} \mathrm{~mol}^{-1}$ & Ref. \\
\hline \multirow[t]{2}{*}[\mathrm{Eu}(\mathrm{DOTAM})(\mathrm{H}_{2}\mathrm{O})]{$^{3+}$} & SAP & $9.4 / 8.8-9.9^{a}$ & 57.5 & +24.1 & +4.9 & 43 and 49 \\
\hline & TSAP & $474 / 400^{a}$ & 47.2 & +22 & & 43 and 49 \\
\hline \multirow[t]{2}{*}[\mathrm{Eu}(\mathrm{DTMA})(\mathrm{H}_{2}\mathrm{O})]{$^{3+}$} & SAP & 8.2 & 59.7 & +30.3 & +6.9 & 43 \\
\hline & TSAP & 357 & 46.7 & +18 & & 43 \\
\hline$\left[\mathrm{Eu}(\mathrm{DOTMAM})\left(\mathrm{H}_{2} \mathrm{O}\right)\right]^{3+}$ & SAP & 11.2 & 57.2 & +24.4 & & 43 \\
\hline$\left[\mathrm{Eu}(\mathrm{DOTAM}-\mathrm{Gly})\left(\mathrm{H}_{2} \mathrm{O}\right)\right]^{-}$ & SAP & $7.8 / 6.3$ & 55.0 & +14.2 & & 104 \\
\hline
\end{tabular}

${ }^{a}$ Values obtained for the $\mathrm{Gd}^{3+}$ complex from ${ }^{17} \mathrm{O}$ NMR measurements.

The water exchange in $\mathrm{Gd}^{3+}$ DOTA-like complexes was in some cases analysed by considering different kinetic parameters for the SAP and TSAP isomers using ${ }^{1} \mathrm{H}$ and/or ${ }^{17} \mathrm{O}$ NMR measurements. Though this approach provides kinetic parameters with relatively high statistical errors, all the results obtained are consistent with a faster water exchange for the TSAP isomers. In the case of $\left[\operatorname{Gd}(\mathrm{DOTAM})\left(\mathrm{H}_{2} \mathrm{O}\right)\right]^{3+}$ the exchange rates determined from ${ }^{17} \mathrm{O}$ NMR measurements on the bulk water signal are in good agreement with those determined from direct observation of the bound water signal for the $\mathrm{Eu}^{3+}$ analogue (Table 2). ${ }^{49}$ The independent water exchange rates of the two isomers were also determined for $\left[\mathrm{Gd}(\mathrm{DOTA})\left(\mathrm{H}_{2} \mathrm{O}\right)\right]^{-}$, $\left[\mathrm{Gd}(\mathrm{DOTMA})\left(\mathrm{H}_{2} \mathrm{O}\right)\right]^{-}$and $[\mathrm{Gd}(\mathrm{HP}-\mathrm{DO} 3 \mathrm{~A})]$ (Table 3, see also Fig. 2 and 3). ${ }^{47,50}$ These studies provided very similar exchange rates for a given isomer of $\left[\mathrm{Gd}(\mathrm{DOTA})\left(\mathrm{H}_{2} \mathrm{O}\right)\right]^{-}$and $\left[\mathrm{Gd}(\mathrm{DOTMA})\left(\mathrm{H}_{2} \mathrm{O}\right)\right]^{-}$, indicating that the faster exchange rate obtained from the global fitting of the data of $\left[\mathrm{Gd}(\mathrm{DOTMA})\left(\mathrm{H}_{2} \mathrm{O}\right)\right]^{-}\left(k_{\mathrm{ex}}^{298}=11.8 \times\right.$ $\left.10^{6} \mathrm{~s}^{-1}\right)$ with respect to $\left[\mathrm{Gd}(\mathrm{DOTA})\left(\mathrm{H}_{2} \mathrm{O}\right)\right]^{-}\left(k_{\mathrm{ex}}^{298}=3.8 \times 10^{6} \mathrm{~s}^{-1}\right)$ is related to a higher abundance of the TSAP isomer in the former. ${ }^{47,51}$

Table 3. Water exchange rate constants and activation enthalpies reported for the SAP and TSAP isomers of $\mathrm{Gd}^{3+}$ complexes.

\begin{tabular}{lllll}
\hline Complex & Isomer & $\boldsymbol{k}_{\mathbf{e x}}^{\mathbf{2 9 8}} \mathbf{\mathbf { 1 0 } ^ { \mathbf { 6 } } \mathbf { s } ^ { \mathbf { - 1 } }}$ & $\mathbf{\Delta \boldsymbol { H } ^ { \ddagger } / \mathbf { k J ~ } \mathbf { ~ m o l } ^ { \mathbf { - 1 } }}$ & Ref. \\
\hline$\left[\mathrm{Gd}(\mathrm{DOTA})\left(\mathrm{H}_{2} \mathrm{O}\right)\right]^{-}$ & SAP & 2.8 & 58.1 & 47 \\
& TSAP & 18.9 & 41.9 & \\
{$\left[\mathrm{Gd}(\mathrm{DOTMA})\left(\mathrm{H}_{2} \mathrm{O}\right)\right]^{-}$} & SAP & 2.7 & 53.4 & 47 \\
& TSAP & 20 & 40.3 & \\
{$\left[\mathrm{Gd}(\mathrm{HP}-\mathrm{DO} 3 \mathrm{~A})\left(\mathrm{H}_{2} \mathrm{O}\right)\right]$} & SAP & 1.6 & 53 & 50 \\
& TSAP & 112 & 15 & \\
{$\left[\mathrm{Gd}(\mathrm{HP}-\mathrm{DO} 3 \mathrm{MA})\left(\mathrm{H}_{2} \mathrm{O}\right)\right]$} & SAP & 15.6 & 58.9 & 81 \\
& TSAP & 333 & 38.3 & \\
\hline
\end{tabular}

${ }^{a}$ Values obtained from ${ }^{17} \mathrm{O}$ NMR measurements.

A strategy that was proved very efficient to control the isomeric population in $\mathrm{Ln}^{3+}$ complexes of DOTMA derivatives is the C-functionalization of the cyclen group, for instance with a nitrobenzyl group. ${ }^{48,52}$ The relative configuration of the chiral centers of the pendant arms and that of the macrocyclic tertiary carbon originates two diasteroisomers that provide exclusively SAP (S-RRRR) and TSAP (S-SSSS) coordination. 
The $k_{\mathrm{ex}}^{298}$ values obtained for the two isomers revealed that water exchange in the TSAP isomer is one order of magnitude faster.

Complexes of DTPA, DTPA-bisamide and related derivatives also form different diasteroisomers in solution. ${ }^{22}$ Rigidification by C-alkylation of DTPA derivatives allowed to separate and investigate independently two diasteroisomers in the case of MS-325. These isomers showed significantly different water exchange rates $\left(k_{\mathrm{ex}}^{298}=3.2\right.$ and $5.9 \times 10^{6} \mathrm{~s}^{-1}$, respectively) ${ }^{53}$ indicating that changes in the isomer ratio may have an impact on the measured water exchange rates of DTPA derivatives as well. A very similar behaviour was observed for the two diasteroisomers of the C-functionalized derivative [Gd(DTPA- $b z$ $\left.\left.\mathrm{NH}_{2}\right)\left(\mathrm{H}_{2} \mathrm{O}\right)\right]^{2-}$ (Fig. 4). ${ }^{54}$
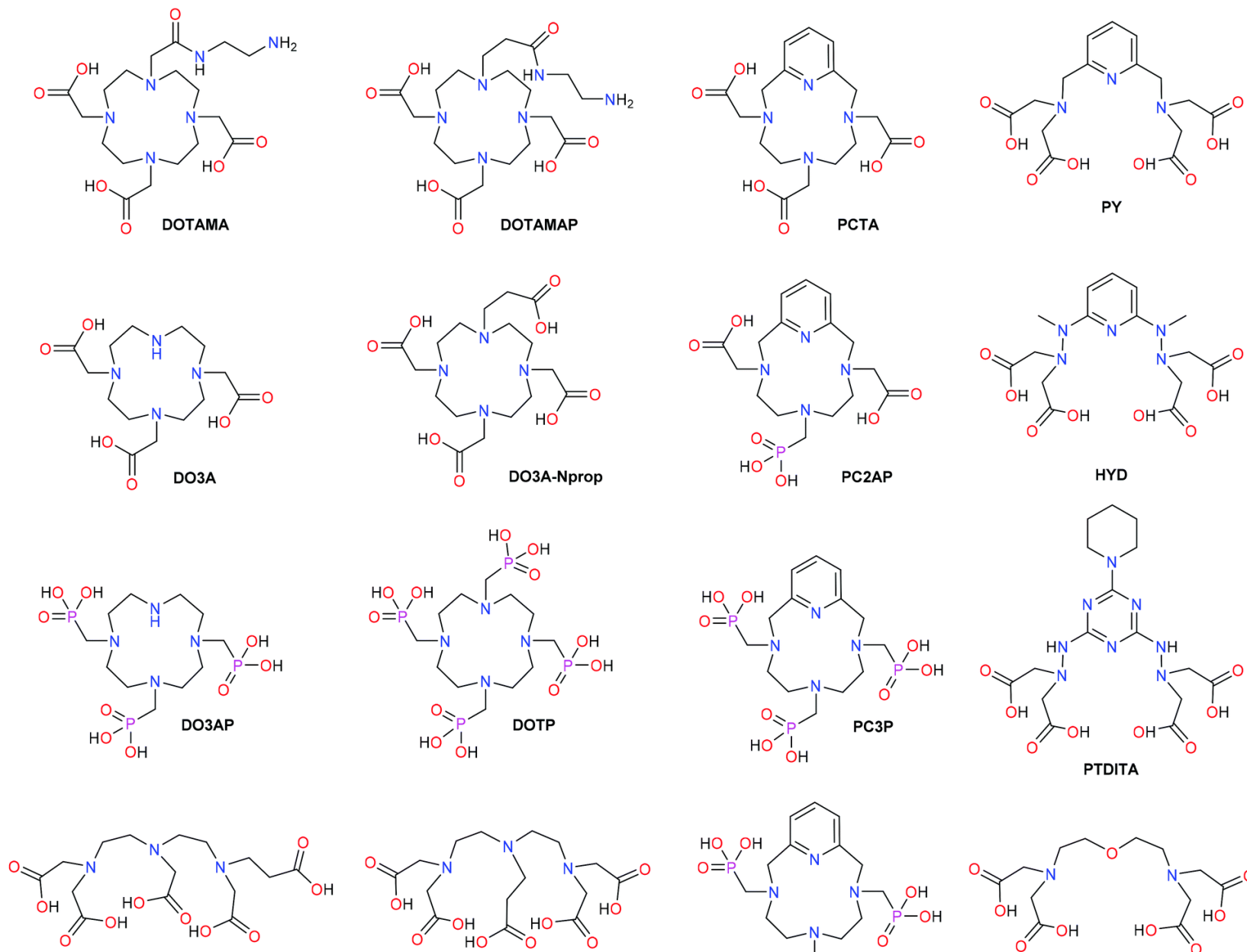

DTTA-Nprop
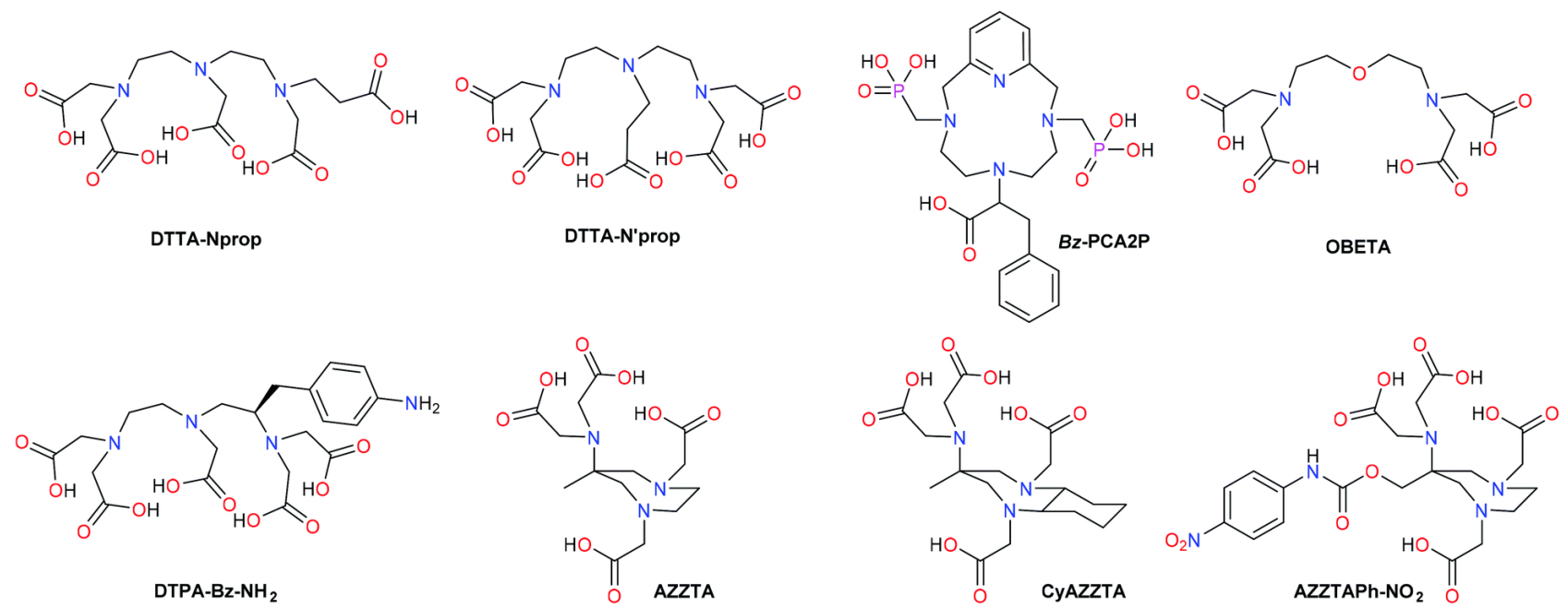

Fig. 4. Multidentate ligands used for complexation of $\mathrm{Ln}^{3+}$. 
A straightforward approach to accelerate water exchange in nine-coordinate $\mathrm{Gd}^{3+}$ complexes is to increase the steric hindrance around the coordinated water molecule. This strategy is illustrated by comparing the $k_{\mathrm{ex}}^{298}$ values of $\left[\mathrm{Gd}(\mathrm{DOTA})\left(\mathrm{H}_{2} \mathrm{O}\right)\right]^{-}\left(k_{\mathrm{ex}}^{298}=4.1 \times 10^{6} \mathrm{~s}^{-1}\right)$ and the analogue deriving from a thirteenmembered macrocyclic ring $\left[\mathrm{Gd}(\mathrm{TRITA})\left(\mathrm{H}_{2} \mathrm{O}\right)\right]^{-}\left(k_{\mathrm{ex}}^{298}=270 \times 10^{6} \mathrm{~s}^{-1}\right.$, see Table 1 and Fig. 2$){ }^{55}$ The steric compression on the inner-sphere water molecule generated by inclusion of an additional carbon atom in the macrocyclic chain facilitates its departure following a dissociatively activated mechanism. Enlarging further the size of the macrocycle prevents the coordination of any water molecule, as shown for $[\mathrm{Eu}(\mathrm{TETA})]^{-56}{ }^{56}$ The activation volume determined for $\left[\mathrm{Gd}(\mathrm{TRITA})\left(\mathrm{H}_{2} \mathrm{O}\right)\right]^{-}\left(\Delta V^{*}=-1.5 \mathrm{~cm}^{3} \mathrm{~mol}^{-1}\right)$ points to an interchange mechanism, which is also characterized by a lower $\Delta H^{\ddagger}$ value and less favourable $\Delta S^{\ddagger}$ (Table 1). ${ }^{57}$

The same concept was applied to the DTPA framework by replacing one of the ethylenediamine units by a propylene bridge to give $\left[\mathrm{Gd}(\mathrm{EPTPA})\left(\mathrm{H}_{2} \mathrm{O}\right)\right]^{2-}$ (Fig. 2). The latter complex presents a water exchange rate two orders of magnitude higher than the parent DTPA complex (Table 1). ${ }^{57}$ Closely related $\left[\mathrm{Gd}(\mathrm{EPTPA})\left(\mathrm{H}_{2} \mathrm{O}\right)\right]^{2-}$ derivatives, C-functionalized at the central carbon atom of the propylene linker, also present fast water exchange reactions. ${ }^{58}$ The same holds for the $\left[\mathrm{Gd}(\mathrm{DTPA}-\mathrm{cMA})\left(\mathrm{H}_{2} \mathrm{O}\right)\right]^{-}$analogue containing a propylene linker replacing one of the ligand ethylene spacers (Fig. 2). ${ }^{59}$

Elongation of one of the arms in DTPA and DOTA scaffolds by replacing an acetate by a propionate pendant arm (DTTA-Nprop; DTTA-N'prop and DO3A-Nprop, Fig. 4) was also proven to be efficient in accelerating water exchange. ${ }^{60}$ An analogous approach was also successfully applied to DOTA-monoamide derivatives DOTAMA and DOTAMAP (Fig. 4). ${ }^{61}$

The principle of increasing the water exchange rate by inducing steric compression was successfully applied by introducing bulky groups such as phosphonates and phosphinates replacing one of the carboxylate arms of a triazacyclononate derivative containing mixed carboxylate and picolinate arms (BPATCN and PBPATCN, Fig. 3), ${ }^{62}$ or in DTPA, ${ }^{63}$ EGTA $^{64}$ or DOTA. ${ }^{65}$ Replacing an acetate arm of DOTA by a pyridine$N$-oxide unit provokes a similar effect. ${ }^{66}$ The additional steric hindrance originated by including two or more phosphonate groups on these scaffolds affords complexes lacking an inner-sphere water molecule (i.e. DO2A2P or DOTP). ${ }^{64,67}$

The effect that replacing acetate by methylenephosphonate groups has in water exchange and hydration number is also observed for the ligands of the PCTA family (Fig. 4). The bis-hydrated [Gd(PCTA) $\left.\left(\mathrm{H}_{2} \mathrm{O}\right)_{2}\right]$ complex presents a relatively fast water exchange $\left(k_{\mathrm{ex}}^{298}=14 \times 10^{6} \mathrm{~s}^{-1}\right)^{68}$ that is slightly increased by the incorporation of a phosphonate group replacing the central carboxylate $\left(k_{\mathrm{ex}}^{298}=17 \times 10^{6} \mathrm{~s}^{-1}\right.$ in [Gd(PC2AP) $\left.\left.\left(\mathrm{H}_{2} \mathrm{O}\right)_{2}\right]^{-}\right){ }^{69}$ The complex of the bis-phosphonated ligand Bz-PCA2P (Fig. 4) presents a reduced hydration number $(q=1)$ with $k_{\mathrm{ex}}^{298}=13 \times 10^{6}$ that is again increased for the complex of the triphosphonate ligand PC3P $\left(k_{\mathrm{ex}}^{298}=167 \times 10^{6} \mathrm{~s}^{-1}\right){ }^{70} \mathrm{The} \mathrm{Gd}^{3+}$ complex of the triazacyclononane derivative BPATCN (Fig. 3) experiences a similar effect on substituting one acetate arm by a methylenephosphonate group, as $k_{\mathrm{ex}}^{298}=$ $0.6 \times 10^{6} \mathrm{~s}^{-1}$ and $34 \times 10^{6} \mathrm{~s}^{-1}$ for $\left[\operatorname{Gd}\left(\operatorname{BPATCN}\left(\mathrm{H}_{2} \mathrm{O}\right)\right]\right.$ and $\left[\operatorname{Gd}\left(\operatorname{PBPATCN}\left(\mathrm{H}_{2} \mathrm{O}\right)\right]\right.$, respectively (Fig. 3). ${ }^{62,71}$

Steric compression was also found to be very efficient in accelerating the water exchange in $\left[\mathrm{Gd}(\mathrm{OCTAPA})\left(\mathrm{H}_{2} \mathrm{O}\right)\right]^{-}$(Fig. 5), which presents a $k_{\mathrm{ex}}^{298}$ value $\left(5.0 \times 10^{6} \mathrm{~s}^{-1}\right)^{72}$ similar to that of $\left[\mathrm{Gd}(\mathrm{DOTA})\left(\mathrm{H}_{2} \mathrm{O}\right)\right]^{-}$(Table 1). Replacing the two acetate groups of OCTAPA by methylenephosphonate arms results in a dramatic increase of water exchange to $k_{\mathrm{ex}}^{298}=700 \times 10^{6} \mathrm{~s}^{-1}$, ${ }^{73}$ which remains the highest water exchange rate reported for a ternary $\mathrm{Gd}^{3+}$ complex, and similar to that of $\left[\mathrm{Gd}\left(\mathrm{H}_{2} \mathrm{O}\right)_{8}\right]^{3+}$ (Fig. 5). The reason for this extremely high water exchange rate was related to the presence in solution of an equilibrium involving monohydrated and a non-hydrated complex species. This ensures a small energy difference between the nine-coordinate ground state and the eight-coordinate transition state responsible for the 
dissociatively activated water exchange mechanism. However, some $\mathrm{Gd}^{3+}$ complexes that present hydration equilibria, such as $\left[\mathrm{Gd}(\mathrm{DO} 3 \mathrm{~A})\left(\mathrm{H}_{2} \mathrm{O}\right)_{q}\right](q=1,2)$ present much slower water exchange rates (see below).

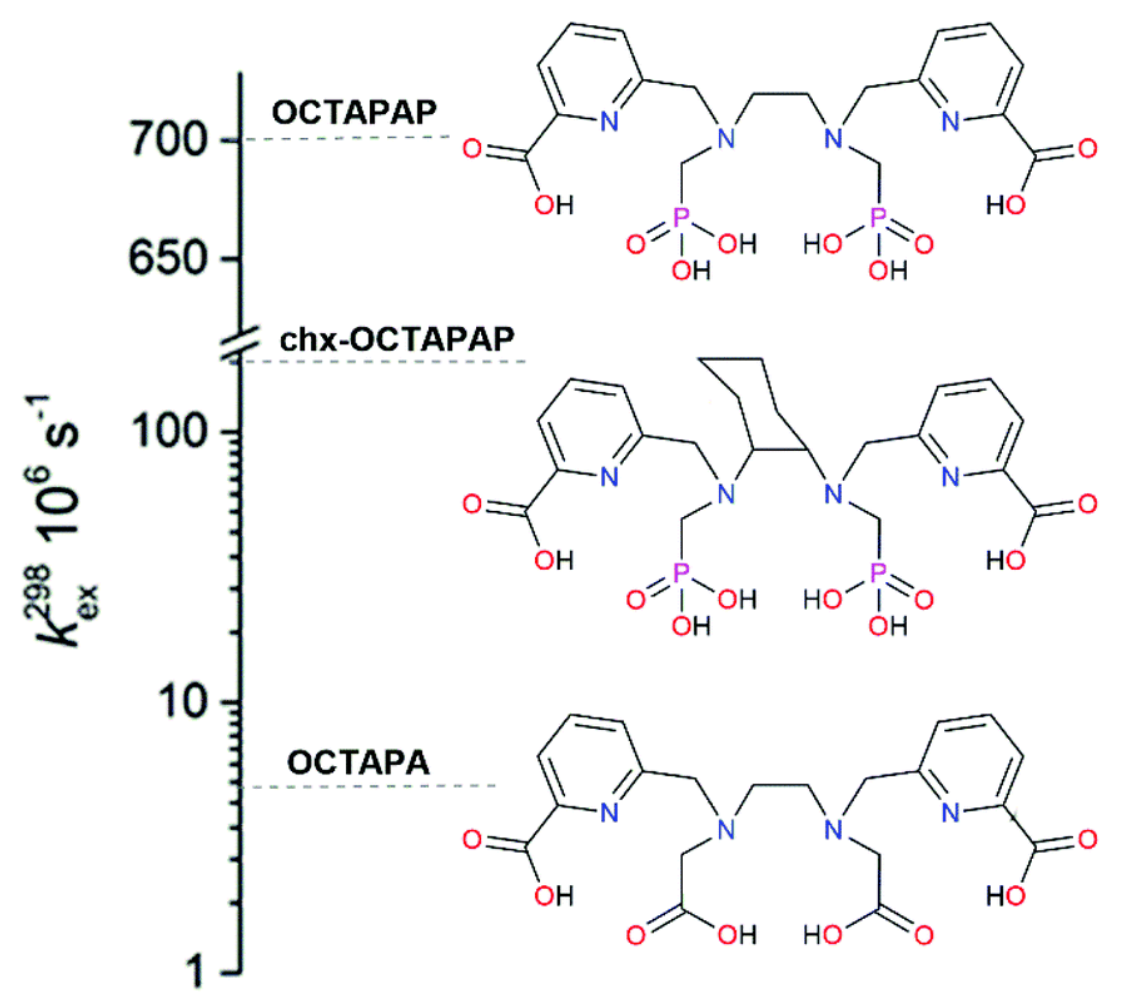

Fig. 5. Effect of steric compression and ligand rigidity on the water exchange rates of $\mathrm{Gd}^{3+}$ complexes of the OCTAPA family.

Another example of steric hindrance, introduced by peripheral groups, is given by the $\left[\mathrm{Gd}(\mathrm{DODPA})\left(\mathrm{H}_{2} \mathrm{O}\right)\right]^{+}$and $[\mathrm{Gd}(\mathrm{MeDODPA})]^{+}$complexes (Fig. 3). The first contains a water molecule with a rather fast exchange with bulk water $\left(k_{\mathrm{ex}}^{298}=58 \times 10^{6} \mathrm{~s}^{-1}\right)$, while the introduction of methyl groups in the ligand backbone results in a $q=0$ complex. ${ }^{74}$

A systematic investigation of the impact of steric compression and complex charge has been performed on $\mathrm{Gd}^{3+}$ complexes based on a cyclen platform, functionalized at positions N4 and N10 with acetate groups, and at position $\mathrm{N} 1$ with a $\alpha$-substituted acetate containing a pentamethyl hydroxybiphenyl moiety to target Human Serum Albumin (HSA). ${ }^{75}$ The substituent attached to N7 was systematically varied and the exchange rate of the coordinated water molecule investigated by variable temperature ${ }^{1} \mathrm{H}$ NMRD studies of the complexes - HSA adduct (Fig. 6). The exchange rates determined for the complexes containing $\alpha$-substituted acids at N7 with charge neutral side chains (Gd1a-Gd1f) were found to present rather different exchange rates that generally increase with increasing the bulkiness of the substituent, particularly if the configuration of the chiral center is $R$ (Table 4, see also Fig. 6). The Gd1h-Gd1j derivatives, which contain charged side chains, also present exchange rates significantly faster than those of the non-substituted derivative Gd1a. This behaviour is likely related to different relative populations of the SAP and TSAP isomers, which were found to be very sensitive to steric hindrance (e.g. for the $\left[\mathrm{Eu}(\mathrm{DOTAM})\left(\mathrm{H}_{2} \mathrm{O}\right)\right]^{3+}$ and $\left[\mathrm{Eu}(\mathrm{DOTMAM})\left(\mathrm{H}_{2} \mathrm{O}\right)\right]^{3+}$ complexes, the populations of the TSAP isomer at $298 \mathrm{~K}$ amount to 0.18 and 0.77 , respectively). ${ }^{43}$ The complexes containing phenolate $(\mathbf{G d 4 a}-\mathbf{4 c})$ or phosphonate $(\mathbf{G d 9 a})$ groups present particularly fast exchange rates, which can be directly linked to the steric compression generated by these bulky group. The same effect was observed for derivatives containing amide substituents in positions N4 and 
$\mathrm{N} 10 .{ }^{76}$ The neutral pyridine $\mathrm{N}$ donor had a similar effect on water exchange to the amide $\mathrm{O}$ donor. Two lesser studied anionic donor groups in $\mathrm{Ln}$ (iii) chemistry, the hydroxamate $\mathrm{O}$ donor and the sulfonamide $\mathrm{N}$ donor, resulted in water exchange rates intermediate between an anionic acetate $\mathrm{O}$ donor and a neutral acetamide donor.<smiles>[Y9]Cc1cc([R2])cc([R2])c1O</smiles>

Fig. 6. Serum albumin binding $\mathrm{Gd}^{3+}$ chelators with differing donor atom types at the $\mathrm{N} 7$ position of the macrocycle to systematically study the effect of water exchange on relaxivity of slow tumbling contrast agents.

An interesting example of combined steric compression generated by phosphonate groups is given by DOTAla and DOTAlaP derivatives (Fig. 7). The [Gd(DOTAla) $\left.\left(\mathrm{H}_{2} \mathrm{O}\right)\right]^{-}$complex presents a water exchange rate of $k_{\mathrm{ex}}^{298}=40 \times 10^{6} \mathrm{~s}^{-1},{ }^{77}$ which is one order of magnitude faster than that of $\left[\mathrm{Gd}(\mathrm{DOTA})\left(\mathrm{H}_{2} \mathrm{O}\right)\right]^{-}\left(k_{\mathrm{ex}}^{298}=\right.$ $4.1 \times 10^{6} \mathrm{~s}^{-1}$, Table 1) as a result of the presence of the bulkier $\alpha$-aminopropionate pendant arm. This fast water exchange rate was exploited to generate linear and cyclic monomers, dimers and trimers with improved relaxivity properties by integrating the single amino acid chelate into different peptides. ${ }^{78}$ Alternatively, high relaxivities can be achieved by incorporating groups that target Human Serum Albumin (HSA). ${ }^{79}$ The substitution of one of the acetate groups of DOTAla by a methylenephosphonate pendant arm to give DOTAlaP results in an even faster water exchange rate $\left(k_{\mathrm{ex}}^{298}=97 \times 10^{6} \mathrm{~s}^{-1}\right){ }^{80}$ which is associated to a weak coordination of the inner-sphere water molecule to the metal ion. As a result, functionalization of the amino acid of DOTAlaP at either the nitrogen or carbon terminus with different $\mathrm{R}$ groups sometimes yield $\mathrm{Gd}^{3+}$ complexes with no inner-sphere water. ${ }^{80}$ 
Table 4. Water exchange rate constants and activation enthalpies for the $\mathrm{Gd}^{3+}$ complexes bound to albumin.

\begin{tabular}{|c|c|c|c|c|c|}
\hline Complex & $k_{\mathrm{ex}}^{298} / 10^{6} \mathrm{~s}^{-1}$ & $\Delta H^{\ddagger} / \mathbf{k J} \mathrm{mol}^{-1}$ & D1 & $\mathbf{R 1}$ & $\mathbf{R 2}$ \\
\hline Gd1a & 8.3 & 42.2 & $\alpha$-Acetate & $\mathrm{H}$ & \\
\hline Gd1b & 26.0 & 42.3 & $\alpha$-Acetate & $R-\mathrm{CH}_{3}$ & \\
\hline Gd1c & 54.0 & 43.7 & $\alpha$-Acetate & $R-\mathrm{CH}\left(\mathrm{CH}_{3}\right)_{2}$ & \\
\hline Gd1d & 17.6 & 56.2 & $\alpha$-Acetate & $S-\mathrm{CH}\left(\mathrm{CH}_{3}\right)_{2}$ & \\
\hline Gd1e & 45.8 & 31.6 & $\alpha$-Acetate & $R$-Cyclohexyl & \\
\hline Gd1f & 11.8 & 41.3 & $\alpha$-Acetate & $S$-Cyclohexyl & \\
\hline Gd1g & 90.4 & 43.3 & $\alpha$-Acetate & $\mathrm{COOH}$ & \\
\hline Gd1h & 23.4 & 47.9 & $\alpha$-Acetate & $R-\mathrm{CH}(\mathrm{OH}) \mathrm{COOH}$ & \\
\hline Gd1i & 36.6 & 47.9 & $\alpha$-Acetate & $R-\mathrm{CH}_{2} \mathrm{CH}_{2} \mathrm{COOH}$ & \\
\hline Gd1j & 13.7 & 40.1 & $\alpha$-Acetate & $R-\left(\mathrm{CH}_{2}\right)_{3}-\mathrm{O}-\mathrm{P}(\mathrm{O})(\mathrm{OH})_{2}$ & \\
\hline Gd2b & 2.06 & 31.3 & Amide & $\mathrm{CH}_{2} \mathrm{COOH}$ & \\
\hline Gd2c & 1.57 & 30.9 & Amide & $\mathrm{CH}_{2} \mathrm{CH}_{2} \mathrm{COOH}$ & \\
\hline Gd2d & 1.59 & 30.6 & Amide & $\mathrm{CH}_{2} \mathrm{CH}_{2} \mathrm{CH}_{2} \mathrm{COOH}$ & \\
\hline Gd2f & 1.72 & 23.9 & Amide & $\mathrm{CH}_{2} \mathrm{P}(\mathrm{O})(\mathrm{OH})_{2}$ & \\
\hline Gd3a & 1.88 & 10.8 & Pyridine & $\mathrm{H}$ & \\
\hline Gd3c & 1.53 & 13.4 & Pyridine & $\mathrm{COOH}$ & \\
\hline Gd3f & 1.57 & 33.3 & Pyrazol & & \\
\hline Gd4a & 1287 & 34.9 & Phenol & $\mathrm{H}$ & $\mathrm{H}$ \\
\hline Gd4b & 478 & 30.5 & Phenol & $\mathrm{H}$ & $\mathrm{OH}$ \\
\hline Gd4c & 376 & 33.8 & Phenol & $\mathrm{NO}_{2}$ & $\mathrm{H}$ \\
\hline Gd7a & 3.28 & 23.2 & Hydroxamate & & \\
\hline Gd8a & 2.44 & 32.1 & Sulfonamide & & \\
\hline Gd9a & 652 & 27.4 & Phosphonate & & \\
\hline
\end{tabular}
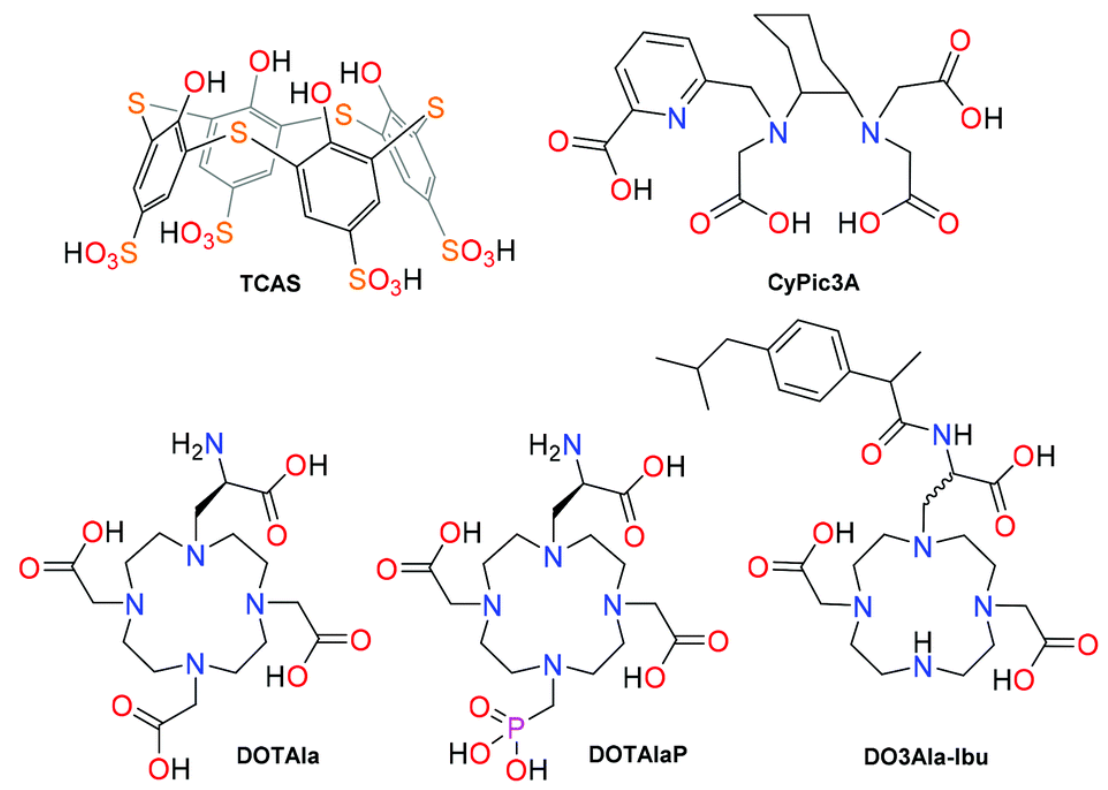

Fig. 7. Macrocyclic and acyclic ligands employed for $\mathrm{Gd}^{3+}$ complexation. 


\section{$\underline{\text { Rigid } v s . \text { flexible systems and hydration number }}$}

The assessment of the role of ligand rigidification on water exchange is not straightforward. For instance, the inclusion of methyl groups at the $\alpha$ positions of the acetate arms affects dramatically the population of SAP and TSAP isomers, which affects water exchange. In a recent work it was shown that the inclusion of methyl groups in the three acetic pendant arms of $\left[\mathrm{Gd}(\mathrm{HP}-\mathrm{DO} 3 \mathrm{~A})\left(\mathrm{H}_{2} \mathrm{O}\right)\right]$ not only affects the population of SAP and TSAP isomers, but also accelerates notably water exchange in both isomers ([Gd(HP-DO3MA) $\left.\left(\mathrm{H}_{2} \mathrm{O}\right)\right]$, Table 3). However, this effect is more likely related to an increased steric compression on the coordinated water molecule than to the rigidity of the system. ${ }^{81}$

Replacing the central ethylene bridge of EGTA by aromatic rigid spacers was proved to accelerate the exchange of the coordinated water molecule by a factor of $2-3 .{ }^{82}$ On the other hand, the introduction of a cyclohexyl ring replacing the ethylene spacer of OCTAPAP causes a significant lowering of the water exchange rate (Fig. 5). ${ }^{73}$ The two complexes present virtually identical thermodynamic parameters for the equilibrium involving the $q=1$ and $q=0$ species, which confirms that this structural modification does not cause significant changes in the metal coordination environment. The lower water exchange was explained by the higher energy cost required to adjust the metal coordination sphere and reach the eight-coordinate transition state upon ligand rigidification.

Table 5 presents water the exchange rates reported for some bis-aquated $\mathrm{Gd}^{3+}$ complexes. Most $q=2$ complexes present faster water exchange than classical mono-aquated $\left[\mathrm{Gd}(\mathrm{DOTA})\left(\mathrm{H}_{2} \mathrm{O}\right)\right]^{-}$and $\left[\mathrm{Gd}(\mathrm{DTPA})\left(\mathrm{H}_{2} \mathrm{O}\right)\right]^{2-}$ (see Table 1 for comparison). Water exchange is particularly fast for $\left[\mathrm{Gd}(\mathrm{PCTA})\left(\mathrm{H}_{2} \mathrm{O}\right)_{2}\right],{ }^{68}\left[\mathrm{Gd}(\mathrm{CyPic} 3 \mathrm{~A})\left(\mathrm{H}_{2} \mathrm{O}\right)_{2}\right]^{-83},{ }^{83}\left[\mathrm{Gd}(\mathrm{DO} 3 \mathrm{Ala}-\mathrm{Ibu})\left(\mathrm{H}_{2} \mathrm{O}\right)_{2}\right]^{84}$ and $\quad$ Gd(DTTA$\left.\mathrm{Me})\left(\mathrm{H}_{2} \mathrm{O}\right)_{2}\right]^{-23}$ although water exchange is somewhat lower in derivatives of the latter. ${ }^{85}$ This can be attributed to the more open and flexible structure of the bis-hydrated complexes, which can more easily accommodate the eight-coordinate transition state following a dissociative mechanism. The dissociative nature of the water exchange reaction was confirmed by the rather large positive activation volume determined for $\left[\mathrm{Gd}(\mathrm{PY})\left(\mathrm{H}_{2} \mathrm{O}\right)_{2}\right]^{-}\left(\Delta V^{*}=+8.8 \mathrm{~cm}^{3} \mathrm{~mol}^{-1}\right)$ and closely related derivatives with substituents at position 4 of the pyridine ring or containing an isoquinoline group replacing the pyridine moiety. ${ }^{86,87} \mathrm{~A}$ slightly positive activation entropy was also reported for $\left[\mathrm{Gd}(\mathrm{DO} 3 \mathrm{~A})\left(\mathrm{H}_{2} \mathrm{O}\right)_{q}\right]\left(\Delta S^{\ddagger}=+2.4 \mathrm{~J} \mathrm{~mol}^{-1} \mathrm{~K}^{-1}\right)$. $^{88}$

Table 5. Water exchange rate constants and activation enthalpies reported for some bis-hydrated $\mathrm{Gd}^{3+}$ complexes.

\begin{tabular}{llll}
\hline Complex & $\boldsymbol{k}_{\mathbf{e x}}^{\mathbf{2 9 8}} \mathbf{1 0}^{\mathbf{6}} \mathbf{s}^{\mathbf{- 1}}$ & $\boldsymbol{\Delta H}^{\star} / \mathbf{k J ~} \mathbf{~ m o l}^{\mathbf{- 1}}$ & Ref. \\
\hline$\left[\mathrm{Gd}(\mathrm{DTTA}-\mathrm{Me})\left(\mathrm{H}_{2} \mathrm{O}\right)_{2}\right]^{-}$ & 24.6 & 50 & 23 \\
{$\left[\mathrm{Gd}(\mathrm{PCTA})\left(\mathrm{H}_{2} \mathrm{O}\right)_{2}\right]$} & 14.3 & 45 & 68 \\
{$\left[\mathrm{Gd}(\mathrm{AAZTA})\left(\mathrm{H}_{2} \mathrm{O}\right)_{2}\right]^{-}$} & 11.1 & $a$ & 93 \\
{$\left[\mathrm{Gd}(\mathrm{CyAAZTA})\left(\mathrm{H}_{2} \mathrm{O}\right)_{2}\right]^{-}$} & 9.1 & 27.8 & 92 \\
{$\left[\mathrm{Gd}(\mathrm{DO} 3 \mathrm{Ala}-\mathrm{Ibu})\left(\mathrm{H}_{2} \mathrm{O}\right)_{2}\right]$} & 28.0 & 25.7 & 84 \\
{$\left[\mathrm{Gd}(\mathrm{CyPic} 3 \mathrm{~A})\left(\mathrm{H}_{2} \mathrm{O}\right)_{2}\right]^{-}$} & 44 & 29.1 & 83 \\
{$\left[\mathrm{Gd}(\mathrm{DO} 3 \mathrm{~A})\left(\mathrm{H}_{2} \mathrm{O}\right)_{4}\right]^{b}$} & 11 & 33.6 & 88 \\
{$\left[\mathrm{Gd}(\mathrm{OBETA})\left(\mathrm{H}_{2} \mathrm{O}\right)_{2}\right]^{-}$} & 13 & 40.1 & 94 \\
{$\left[\mathrm{Gd}(\mathrm{PY})\left(\mathrm{H}_{2} \mathrm{O}\right)_{2}\right]^{-}$} & 9.3 & 50.4 & 86 \\
{$\left[\mathrm{Gd}(\mathrm{HYD})\left(\mathrm{H}_{2} \mathrm{O}\right)_{2}\right]^{-}$} & 7.8 & 43.5 & 96 \\
{$\left[\mathrm{Gd}(\mathrm{PTDITA})\left(\mathrm{H}_{2} \mathrm{O}\right)_{2}\right]^{-}$} & 3.3 & 37.7 & 89 \\
\hline
\end{tabular}

${ }^{a}$ Not reported. ${ }^{b}$ A hydration equilibrium exists in solution with $q=1.88$ at $298 \mathrm{~K}$. 
The fast water exchange of bis-hydrated complexes is not however a general rule, as a few $q=2$ complexes with slow water exchange have been reported. For instance $\left[\mathrm{Gd}(\mathrm{PTDITA})\left(\mathrm{H}_{2} \mathrm{O}\right)_{2}\right]^{-}$presents a rather low $k_{\mathrm{ex}}^{298}$ value (Table 5), ${ }^{89}$ comparable to that of $\left[\mathrm{Gd}(\mathrm{DTPA})\left(\mathrm{H}_{2} \mathrm{O}\right)\right]^{2-}$. A more striking example is provided by the bis-hydrated MS-325 derivative in which a methyl group replaces one of the terminal acetate arms of MS-325. The $\mathrm{Gd}^{3+}$ complex of this heptadentate ligand presents a particularly low water exchange $\left(k_{\mathrm{ex}}^{298}=\right.$ $\left.0.44 \times 10^{6} \mathrm{~s}^{-1}\right)$ when compared to that of the MS-325 complex $\left(k_{\mathrm{ex}}^{298}=5.8 \times 10^{6} \mathrm{~s}^{-1}\right) \cdot{ }^{90}$ It is clear that this apparently innocent change in the ligand backbone provokes an important change in the relative stabilities of the nine-coordinate ground state and the eight-coordinate transition state responsible for the dissociative water exchange mechanism. A extremely slow water exchange $\left(k_{\mathrm{ex}}^{298}=8.6 \times 10^{3} \mathrm{~s}^{-1}\right)$ was also observed for a trinuclear $\mathrm{Gd}^{3+}$ complex with the thiacalix[4]arene ligand TCAS (Fig. 7), which contains two coordinated water molecules per $\mathrm{Gd}^{3+}$ ion. ${ }^{91}$

A lower water exchange rate was measured for $\left[\mathrm{Gd}(\mathrm{CyAAZTA})\left(\mathrm{H}_{2} \mathrm{O}\right)_{2}\right]^{-}$compared to $\left[\mathrm{Gd}(\mathrm{AAZTA})\left(\mathrm{H}_{2} \mathrm{O}\right)_{2}\right]^{-},{ }^{92,93}$ which can be attributed to the rigidifying effect introduced by the cyclohexyl ring fused with the methylperhydro-1,4-diazepine moiety of AAZTA. Similarly, the short spacer connecting the two iminodiacetate units of $\left[\mathrm{Gd}(\mathrm{OBETA})\left(\mathrm{H}_{2} \mathrm{O}\right)_{2}\right]^{-}$is likely resulting in a more rigid structure that furnishes a lower $k_{\mathrm{ex}}^{298}$ value with respect to the closely related $\left[\mathrm{Gd}(\mathrm{EGTA})\left(\mathrm{H}_{2} \mathrm{O}\right)\right]^{-}$complex. ${ }^{94}$ Finally, the rigidified versions of $\left[\mathrm{Gd}(\mathrm{PY})\left(\mathrm{H}_{2} \mathrm{O}\right)_{2}\right]^{-},\left[\mathrm{Gd}(\mathrm{HYD})\left(\mathrm{H}_{2} \mathrm{O}\right)_{2}\right]^{-}$and $\left[\mathrm{Gd}(\mathrm{PTDITA})\left(\mathrm{H}_{2} \mathrm{O}\right)_{2}\right]^{-}$, also show lower water exchange rates than the parent complex, which for $\left[\mathrm{Gd}(\mathrm{HYD})\left(\mathrm{H}_{2} \mathrm{O}\right)_{2}\right]^{-}$is also reflected in slower dissociation kinetics. ${ }^{95,96}$

\section{The labile capping bond phenomenon}

Recent studies performed on a series of isomeric $\mathrm{Gd}^{3+}$ complexes revealed that water exchange is intimately related to the position of the water molecule in the coordination polyhedron. This is rather obvious when comparing the exchange rates of the coordinated water molecules in the $\left[\mathrm{Gd}(1,4-\mathrm{MeDO} 2 \mathrm{APA})\left(\mathrm{H}_{2} \mathrm{O}\right)\right]$ and [Gd(1,7-MeDO2APA $\left.)\left(\mathrm{H}_{2} \mathrm{O}\right)\right]$ complexes, which differ in the relative positions of the two acetate pendants attached to the macrocyclic cyclen unit (Fig. 8) ${ }^{97}$ The two complexes present capped square antiprismatic coordination environments, with the capping position being occupied by a water molecule or an oxygen atom of the picolinate group in $\left[\mathrm{Gd}(1,4-\mathrm{MeDO} 2 \mathrm{APA})\left(\mathrm{H}_{2} \mathrm{O}\right)\right]$ and $\left[\mathrm{Gd}(1,7-\mathrm{MeDO} 2 \mathrm{APA})\left(\mathrm{H}_{2} \mathrm{O}\right)\right]$, respectively. Water exchange was found to be four orders of magnitude faster for the [Gd(1,4-MeDO2APA $)\left(\mathrm{H}_{2} \mathrm{O}\right)$ ] complex, as the inner-sphere water molecule is occupying a capping position, and thus hindered by the environment (Table 6). As a result, the eight-coordinate transition state facilitating the dissociative pathway is easily accessible. In $\left[\mathrm{Gd}(1,7-\mathrm{MeDO} 2 \mathrm{APA})\left(\mathrm{H}_{2} \mathrm{O}\right)\right]$ the coordinated water molecule is more tightly bound to the metal ion, resulting in a much lower exchange rate. Relatively low water exchange rates were also observed for the closely related complexes [Gd(1,7-DO2APA $\left.)\left(\mathrm{H}_{2} \mathrm{O}\right)\right]$ and $\left[\mathrm{Gd}(1,7-\mathrm{DO} 2 \mathrm{APAOA})\left(\mathrm{H}_{2} \mathrm{O}\right)\right]$ (Fig. 8) ${ }^{98}$ when compared to $\left[\mathrm{Gd}(1,4-\mathrm{MeDO} 2 \mathrm{APA})\left(\mathrm{H}_{2} \mathrm{O}\right)\right]$. Interestingly, the presence of a methyl group in $\left[\mathrm{Gd}(1,7-\mathrm{MeDO} 2 \mathrm{APA})\left(\mathrm{H}_{2} \mathrm{O}\right)\right]$ slows down water exchange by a factor of $\sim 30$, suggesting that hydrogen bonding between the coordinated water molecule and the $\mathrm{NH}$ group of $\left[\mathrm{Gd}(1,7-\mathrm{DO} 2 \mathrm{APA})\left(\mathrm{H}_{2} \mathrm{O}\right)\right]$ may facilitate the departure of the inner-sphere water molecule following a dissociative mechanism.

The same effect, though less pronounced, is also observed by comparing the water exchange rates of $\left[\mathrm{Gd}(4,7-\mathrm{PY} 2 \mathrm{APA})\left(\mathrm{H}_{2} \mathrm{O}\right)\right]$ and $\left[\mathrm{Gd}(4,10-\mathrm{PY} 2 \mathrm{APA})\left(\mathrm{H}_{2} \mathrm{O}\right)\right]$ (Table 6, Fig. 8). ${ }^{99}$ This phenomenon has implications for the water exchange in bis-aquated complexes. For instance, it is likely that the two innersphere water molecules in $\left[\mathrm{Gd}(\mathrm{DO} 3 \mathrm{~A})\left(\mathrm{H}_{2} \mathrm{O}\right)_{2}\right]$ and other bis-hydrated complexes are endowed with different water exchange rates, the experimentally determined $k_{\mathrm{ex}}^{298}$ reflecting weighted averages of the contributions of the two coordinated water molecules. Computational studies supported that the capping water molecule in $\left[\mathrm{Gd}(\mathrm{DO} 3 \mathrm{~A})\left(\mathrm{H}_{2} \mathrm{O}\right)_{2}\right]$ and other bis-aquated complexes is considerably more labile. ${ }^{38} \mathrm{~A}{ }^{17} \mathrm{O}$ NMR study on the trinuclear $\left[\mathrm{Gd}_{3}(\mathrm{TCAS})_{2}\right]^{7-}$ complex also suggested the presence of water molecules with very slow exchange but likely fast-exchanging water molecules as well. ${ }^{91}$ 
<smiles>CN1CCN(CC(=O)O)CCN(CC(=O)O)CCN(Cc2cccc(C(=O)O)n2)CC1</smiles>

1,4-MeDO2APA<smiles>CN1CCN(CC(=O)O)CCN(Cc2cccc(C(=O)O)n2)CCN(CC(=O)O)CC1</smiles>

1,7-MeDO2APA<smiles>O=C(O)CN1CCNCCN(CC(=O)O)CCN(Cc2cccc(C(=O)O)n2)CC1</smiles>

1,7-DO2APA<smiles>O=C(O)CN1CCN(CC(=O)O)Cc2cccc(n2)CN(Cc2cccc(C(=O)O)n2)CC1</smiles>

4,7-PY2APA<smiles>O=C(O)CN1CCN(CC(=O)O)Cc2cccc(n2)CN(CC(=O)O)CC1</smiles>

4,10-PY2APA<smiles>O=C(O)COCCN1CCN(CC(=O)O)CCNCCN(CC(=O)O)CC1</smiles>

1,7-DO2AOA

Fig. 8. Ligands used to showcase the labile capping bond phenomenon.

Table 6. Water exchange rate constants and activation enthalpies of $\mathrm{Gd}^{3+}$ complexes that showcase the labile capping bond phenomenon.

\begin{tabular}{|c|c|c|c|}
\hline Complex & $k_{\mathrm{ex}}^{298} / 10^{6} \mathrm{~s}^{-1}$ & $\Delta H^{\ddagger} / \mathrm{kJ} \mathrm{mol}^{-1}$ & Ref. \\
\hline$\left[\mathrm{Gd}(1,4-\mathrm{MeDO} 2 \mathrm{APA})\left(\mathrm{H}_{2} \mathrm{O}\right)\right]$ & 11.97 & 29.8 & 97 \\
\hline$\left[\mathrm{Gd}(1,7-\mathrm{MeDO} 2 \mathrm{APA})\left(\mathrm{H}_{2} \mathrm{O}\right)\right]$ & 0.0088 & 51.9 & 97 \\
\hline$\left[\mathrm{Gd}(1,7-\mathrm{DO} 2 \mathrm{APA})\left(\mathrm{H}_{2} \mathrm{O}\right)\right]$ & 0.259 & 30.5 & 98 \\
\hline$\left[\mathrm{Gd}(1,7-\mathrm{DO} 2 \mathrm{AOA})\left(\mathrm{H}_{2} \mathrm{O}\right)\right]$ & 0.310 & 34.1 & 98 \\
\hline$\left[\mathrm{Gd}(4,7-\mathrm{PY} 2 \mathrm{APA})\left(\mathrm{H}_{2} \mathrm{O}\right)\right]$ & 22.5 & 37.5 & 99 \\
\hline$\left[\mathrm{Gd}(4,10-\mathrm{PY} 2 \mathrm{APA})\left(\mathrm{H}_{2} \mathrm{O}\right)\right]$ & 1.08 & 28.6 & 99 \\
\hline
\end{tabular}




\section{Effect of peripheral groups and environmental effects}

The nature of the counterion or the addition of salts is likely having a negligible impact in the water exchange kinetics of complexes having fast water exchange. ${ }^{100}$ However, early studies reported by Parker and Botta revealed that water exchange in slow-exchanging DOTA-tetraamide derivatives is heavily influenced by the nature of the counterion present in solution. ${ }^{101}$ The measured water exchange rates followed the order $\mathrm{I}^{-}>\mathrm{Br}^{-}>\mathrm{Cl}^{-}$. They found that nitrate, trifluoromethanesulfonate, trifluoroacetate, and chloride salts of DOTA-tetraamide derivatives exchange coordinated water more slowly, while the sulfate complex exhibited the slowest water exchange of all. These authors related a slower water exchange with a more important ability of the anion to break the hydrogen-bonding structure of the second coordination sphere. This may increase the activation energy barrier due to the perturbation of water structure required for the dissociative water exchange pathway. A similar effect is probably responsible for the lower water exchange rate measured for the same systems in acetonitrile with respect to water. Indeed, water exchange rates were found to be twice as fast in water than in acetonitrile for the same DOTA-tetraamide complexes. ${ }^{102}$ Crystallographic studies revealed that the $\mathrm{Gd}-\mathrm{O}_{\text {water }}$ distance in $\left[\operatorname{Gd}(\mathrm{DOTAM})\left(\mathrm{H}_{2} \mathrm{O}\right)\right]^{3+}$ is very sensitive to the hydrogen-bonding network involving the coordinated water molecule. ${ }^{103}$

A wide range of $\mathrm{Eu}^{3+}$ DOTA-tetraamide complexes was synthesized in an attempt to modulate the water exchange rate of the coordinated water molecule, which is a key parameter to develop efficient CEST agents. These studies revealed several factors that affect water exchange in this family of complexes, although a full rationalization of the results has not been achieved yet. The determination of $k_{\mathrm{ex}}$ values for such systems from CEST spectra might be also misleading if several species with significantly different water exchange rates provide CEST signals with similar chemical shifts, ${ }^{104}$ or in the presence of a pool of fast exchanging protons. ${ }^{105}$ Nevertheless, some trends observed for close related systems shed light on some important factors:

(i) Effect of pH. The exchange rate of the coordinated water molecule was found to be very sensitive to $\mathrm{pH}$. This was first demonstrated for $\left[\mathrm{Gd}(\mathrm{DOTAM})\left(\mathrm{H}_{2} \mathrm{O}\right)\right]^{3+}$ and other complexes with DOTA-tetraamide ligands, which showed a sharp increase in relaxivity at $\mathrm{pH}>8$ due to based-catalyzed prototropic exchange associated to the deprotonation of the coordinated water molecule. ${ }^{32,106}$ Modulation of water exchange with $\mathrm{pH}$ was also observed in the case of DOTA-tetraamide complexes with side chains containing groups undergoing protonation close to neutral $\mathrm{pH}$ (i.e. phosphonate ${ }^{107}$ or amine ${ }^{108}$ groups). The CEST response of [Eu(DOTAM-Gly) $\left.\left(\mathrm{H}_{2} \mathrm{O}\right)\right]^{-}$was also found to be $\mathrm{pH}$-dependent, with the CEST effect disappearing at low $\mathrm{pH}$ due to an acceleration of water exchange associated to prototropic exchange. ${ }^{109} \mathrm{In}$ some instances the exact mechanism responsible for the $\mathrm{pH}$ responsiveness was not discerned. ${ }^{110}$

(ii) Lipophilicity of the substituents and steric effects. Water exchange in $\mathrm{Eu}^{3+}$ DOTA-tetraamide complexes was also found to be very sensitive to the nature of the substituents at the amide nitrogen atom. In particular, water exchange was found to slow down as the lipophilicity of the side substituents increased. The introduction of more hydrophobic substituents disfavors the presence of a second-hydration sphere with a well-defined hydrogen-bonded structure, increasing the activation barrier associated to the water exchange reaction. ${ }^{11}$ This was supported by a correlation found between the water exchange rate and solvent accessible surface for second-sphere water molecules. Subsequent studies reported by Sherry and coworkers showed that additional factors are also affecting significantly water exchange. For instance, an increase of the steric bulk of the amide substituent in $\mathrm{Eu}^{3+}$ DOTAM derivatives from isopropyl to $t$-butyl to 3-pentyl to 4-heptyl resulted in shorter water residence lifetimes, perhaps because steric interactions among the bulky substituents increase the exposure of the coordinated water molecule to bulk water. ${ }^{112}$ Replacing one methyl substituent of the $t$-butyl group in each pendant arm by a carboxyl group lowered water exchange by a factor of 10, while the corresponding ethyl ester derivative presents an even slower water exchange by a factor of two (Fig. 9). ${ }^{112}$ The ethyl ester derivative of $\left[\mathrm{Eu}(\text { DOTAM-Gly })\left(\mathrm{H}_{2} \mathrm{O}\right)\right]^{-}$also presents a slower water exchange with respect to the parent complex. ${ }^{44}$ Thus, the combination of hydrophobic units with carboxylate 
or carboxylate ester groups in the side chains of DOTAM derivatives appears to be adequate for the design of CEST agents with particularly slow water exchange, as confirmed recently by a combinatorial study. ${ }^{113}$ Phosphonate ester groups were proved to be even more efficient in increasing the residence time of the coordinated water molecule. ${ }^{17}$ These features were combined in compound $\left[\mathrm{Eu}(6)\left(\mathrm{H}_{2} \mathrm{O}\right)\right]^{-}$(Fig. 9), which contains charged glutamyl groups and hydrophobic phosphonate ester units, providing a complex with a particularly slow water exchange. Theoretical calculations on the $\mathrm{Yb}^{3+}$ analogue showed that the coordinated water molecule is placed in a hydrophobic pocket of neutral electrostatic potential (Fig. 9). This is likely minimizing hydrogen-bonding interaction between the inner sphere water molecules and nearby functional groups. Furthermore, the bulky phosphonate ethyl ester groups on the periphery of the complex likely restrict the conformational freedom of the glutamyl side chains, resulting in a smaller solvent accessible surface. ${ }^{33}$ The formation of micelles by incorporating aliphatic chains to $\mathrm{Eu}^{3+}$ DOTA-tetraamide complexes was also shown to slow down water exchange, resulting in improved CEST properties. ${ }^{114}$

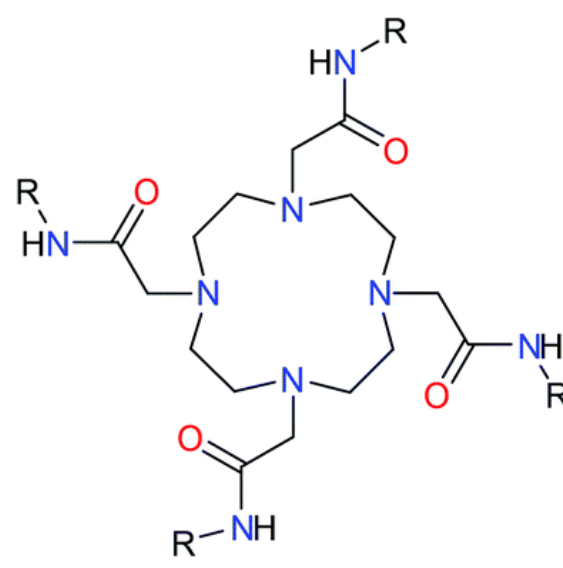

(1) $R={ }^{\mathrm{t}} \mathrm{Bu}$

$k_{\mathrm{ex}}^{298}=10^{5} \mathrm{~s}^{-1}$

(2) $\mathrm{R}=\mathrm{C}\left(\mathrm{CH}_{3}\right)_{2} \mathrm{COOH}$

$k_{\mathrm{ex}}^{298}=9615 \mathrm{~s}^{-1}$

(3) $\mathrm{R}=\mathrm{C}\left(\mathrm{CH}_{3}\right)_{2} \mathrm{COOEt} \quad k_{\mathrm{ex}}{ }^{298}=4762 \mathrm{~s}^{-1}$

(4) $\mathrm{R}=\mathrm{CH}_{2} \mathrm{COOH} \quad k_{\mathrm{ex}}{ }^{298}=6250 \mathrm{~s}^{-1}$

(5) $\mathrm{R}=\mathrm{CH}_{2} \mathrm{COOEt} \quad k_{\mathrm{ex}}{ }^{298}=2710 \mathrm{~s}^{-1}$

(6) $R=$<smiles>CCOP(=O)(CNC(=O)C(C)CC(=O)O)OCC</smiles>

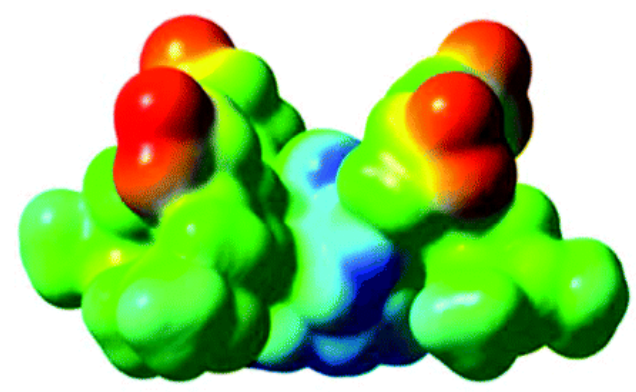

$-0.2$

$+0.1$

Fig. 9. Water exchange rates determined for DOTA-tetraamide derivatives (top) and electrostatic potential (Hartree) calculated on the molecular surface of $\left[\mathrm{Yb}(6)\left(\mathrm{H}_{2} \mathrm{O}\right)\right]^{-}$defined by a 0.001 electrons bohr $^{-3}$ isosurface of electronic density. Adapted with permission from ref. 33. Copyright (C) 2016, American Chemical Society.

The addition of polyethylene glycol chains with increased length to ligands of the HOPO family (Fig. 2) or to DOTA-monoamide derivatives decreased the water exchange rate in a rational manner. ${ }^{115,116}$ This is an interesting observation, since the two families of complexes present different water exchange mechanisms. In the case of HOPO derivatives it was proposed that the PEG chains could decrease the local water concentration in the vicinity of the coordinated water molecule, which would result in a slower water exchange. ${ }^{115}$ 
(iii) Electronic effects. Electronic effects originated by remote substituents were also found to alter significantly water exchange in $\mathrm{Eu}^{3+}$ complexes of DOTA-tetraamide derivatives. Sherry et al. hypothesized that the introduction of electron-donating substituents at the para position of a phenylamide group should increase the donor character of the amide oxygen, weakening the $\mathrm{Eu}-\mathrm{O}_{\text {water }}$ interaction and accelerating water exchange (Fig. 10). ${ }^{117}$ Indeed, water exchange was found to be faster for complexes containing an electrondonating group $(\mathrm{OMe})$ and slower for complexes having electron-withdrawing groups $\left(\mathrm{CN}, \mathrm{CO}_{2}{ }^{t} \mathrm{Bu}\right)$. In another study, a more negative charge on the coordinated amide oxygen atoms was found to correlate with a faster water exchange. ${ }^{118}$ However, this trend was reversed when substituents originating inductive effects, as the introduction of a Me substituent slowed water exchange and the electron-withdrawing $\mathrm{F}$ substituent resulted in a faster water exchange. ${ }^{117}$

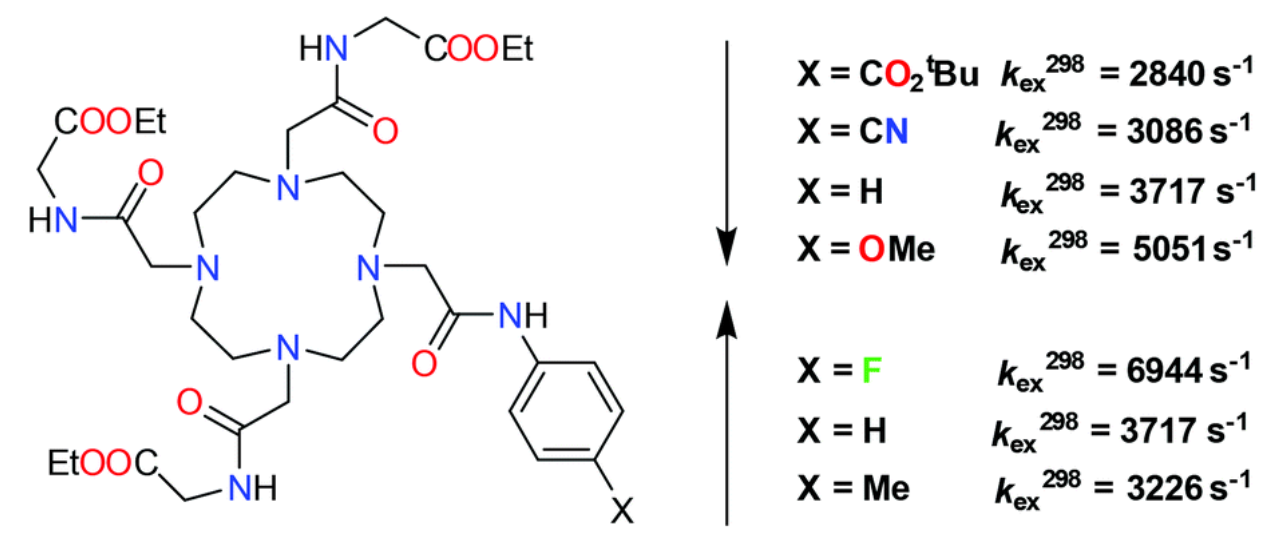

Fig. 10. Ligands used to modulate water exchange in $\mathrm{Eu}^{3+}$ complexes via electronic effects and their corresponding $k_{\mathrm{ex}}^{298}$ values.

(iv) Configuration of the side chains. A few studies have shown that the configuration of the side chains in $\mathrm{Eu}^{3+}$ DOTA-tetraamide derivatives may have an important impact on the exchange rates of the coordinated water molecule, even if only SAP isomers are formed. This was first shown by Sherry for a series of complexes having an asymmetric carbon in $\alpha$ position with respect to the amide nitrogen. ${ }^{119}$ Racemization of the side chains occurring during the ligand synthesis led to the formation of multiple isomers with SAP coordination. The CEST peaks of the individual isomers could be detected at low temperature, thereby allowing the determination of the corresponding water exchange rates, which were found to vary significantly. A second example is illustrated in Fig. $11,{ }^{104}$ which shows the four possible stereoisomers that may be formed for a DOTA-tetraamide complex having a $S$ configuration for the asymmetric carbon of the side chains. NMR studies evidenced the almost exclusive formation of the two SAP diastereoisomers, which also provided separate signals for the coordinated water molecule in the CEST spectra recorded at low temperature. The water exchange rate determined for one of the isomers $\left(k_{\mathrm{ex}}^{298}=5.2 \times 10^{3} \mathrm{~s}^{-1}\right)$, presumably the $S S-\Lambda(\delta \delta \delta \delta)$ isomer, was found to be $c a$. four times slower than that of the second isomer $\left(k_{\mathrm{ex}}^{298}=19.0 \times\right.$ $10^{3} \mathrm{~s}^{-1}$ ), which was assigned as $S S-\Delta(\lambda \lambda \lambda \lambda)$. Thus, the presence of asymmetric carbon atoms on the side chains may generate different diastereoisomeric complexes with very different water exchange rates, in spite of adopting the same SAP coordination. 


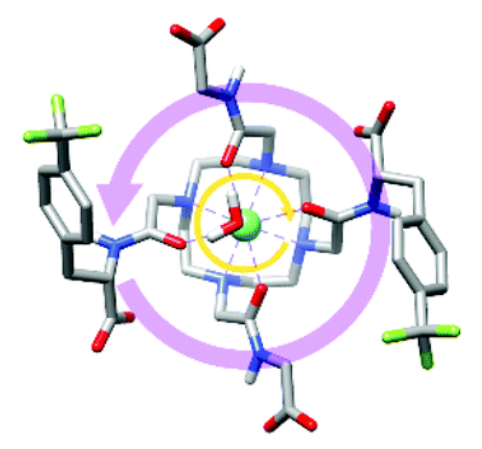

$S S-\Delta(\lambda \lambda \lambda \lambda)$, SAP

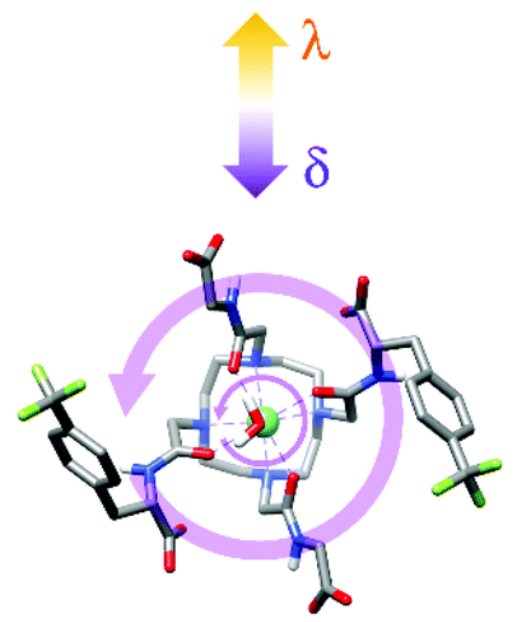

SS- $\Delta(\delta \delta \delta \delta)$, TSAP

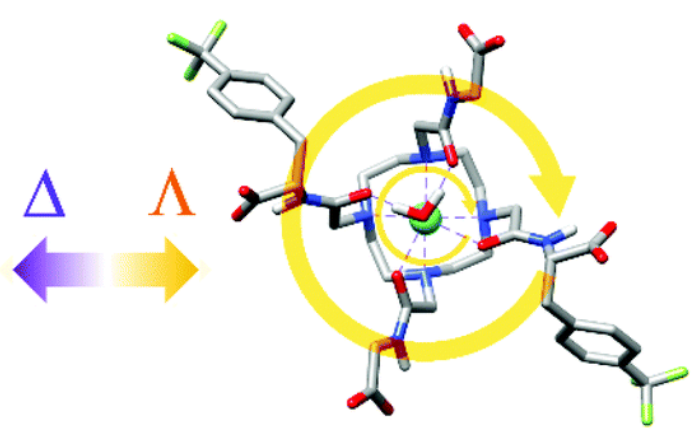

SS- $\Lambda(\lambda \lambda \lambda \lambda)$, TSAP

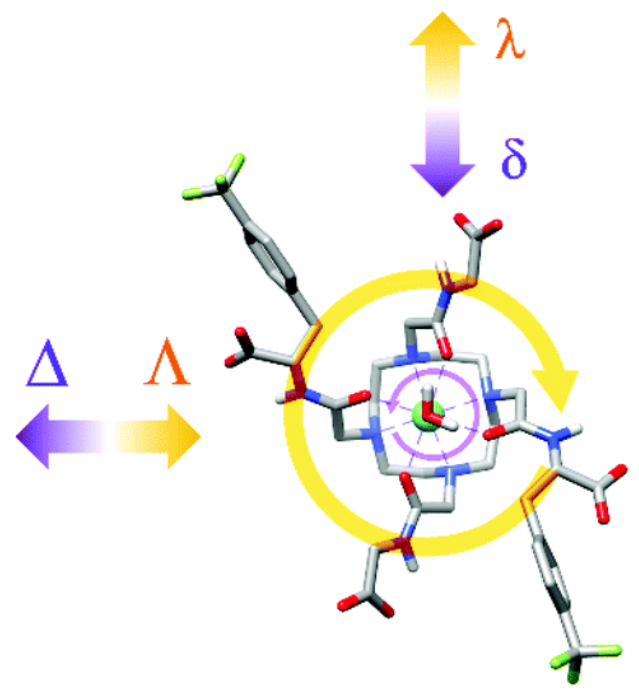

$S S-\Lambda(\delta \delta \delta \delta)$, SAP

Fig. 11. Diastereoisomers with square aniprismatic (SA) and twisted-square aniprismatic (TSAP) geometries showing different helicity as reported in ref. 104.

(v) Hydrogen bonds with peripheral groups. Water exchange in $\mathrm{Gd}^{3+} \mathrm{DO} 3 \mathrm{~A}$ derivatives containing acetophenone pendant arms was found to be accelerated by the presence of hydrogen-bonding donor or acceptor groups in the periphery of the water binding site (Fig. 12). ${ }^{120}$ Indeed, the [Gd(DO3A-AP) $\left.\left(\mathrm{H}_{2} \mathrm{O}\right)\right]$ complex presents water exchange rates for the SAP and TSAP isomers that are typical of charge-neutral DO3A derivatives, the exchange observed the TSAP isomer being 50 times faster than that of the SAP isomer (Table 7). The introduction of a hydroxyl group at position 2 of the acetophenone moiety provokes a remarkable increase of the water exchange rates of the two isomers, both above and below the $\mathrm{p} K_{\mathrm{a}}$ of the hydroxyl group $\left(\mathrm{p} K_{\mathrm{a}}=7.01\right)$. However, the water exchange of the $\left[\mathrm{Gd}(\mathrm{DO} 3 \mathrm{~A}-p \mathrm{HAP})\left(\mathrm{H}_{2} \mathrm{O}\right)\right]$ complex, which contains a hydroxyl group at position 4 of the acetophenone group does not show such fast exchange, particularly in the case of the SAP isomer. It is important to note that the SAP isomer is the major form of these complexes in solution, with abundancies of $72-78 \%$. As a result, the kinetic parameters of the SAP isomer can be determined to a higher accuracy. The high water exchange rates determined for [Gd(DO3A$\left.p \mathrm{HAP})\left(\mathrm{H}_{2} \mathrm{O}\right)\right]$ were justified by the formation of hydrogen bonds involving the coordinated water molecule and the phenol/phenolate group. These hydrogen bonds lower the energy of the eight-coordinate transition state responsible for the dissociatively activated water exchange mechanism, thus accelerating water exchange. A similar effect is probably responsible for the faster water exchange observed for $[\mathrm{Gd}(1,7-$ $\left.\mathrm{DO} 2 \mathrm{APA})\left(\mathrm{H}_{2} \mathrm{O}\right)\right]\left(k_{\mathrm{ex}}^{298}=259 \times 10^{3} \mathrm{~s}^{-1}\right)$, which contains a secondary amine $\mathrm{NH}$ group close to the coordinated water molecule, and the methylated analogue $\left[\mathrm{Gd}(1,7-\mathrm{MeDO} 2 \mathrm{APA})\left(\mathrm{H}_{2} \mathrm{O}\right)\right]\left(k_{\mathrm{ex}}^{298}=8.8 \times\right.$ $\left.10^{3} \mathrm{~s}^{-1}\right) \cdot{ }^{97,98}$ 
<smiles>O=C(O)CN1CCN(CC(=O)O)CCN(CC(=O)O)CCN(CC(=O)O)CC1</smiles>

DO3A-OHAP<smiles>O=C(O)CN1CCN(CC(=O)O)CCN(CC(=O)c2ccc(O)cc2)CCN(CC(=O)O)CC1</smiles>

DO3A-pHAP

Fig. 12. DO3A-type ligands containing acetophenone pendant arms.

Table 7. Water exchange rate constants determined for $\mathrm{Gd}^{3+}$ complexes with DO3A ligands containing an acetophenone pendant $\operatorname{arm}^{a}$

\begin{tabular}{lll}
\hline Complex & Isomer & $\boldsymbol{k}_{\mathbf{e x}}^{\mathbf{2 9 8}} / \mathbf{1 0}^{\mathbf{6}} \mathbf{s}^{\mathbf{- 1}}$ \\
\hline$\left[\mathrm{Gd}(\mathrm{DO} 3 \mathrm{~A}-\mathrm{AP})\left(\mathrm{H}_{2} \mathrm{O}\right)\right]$ & SAP & 0.83 \\
& TSAP & 40 \\
{$\left[\mathrm{Gd}(\mathrm{DO} 3 \mathrm{~A}-o \mathrm{HAP})\left(\mathrm{H}_{2} \mathrm{O}\right)\right]^{b}$} & SAP & 4.8 \\
& TSAP & 455 \\
{$\left[\mathrm{Gd}(\mathrm{DO} 3 \mathrm{~A}-o \mathrm{HAP})\left(\mathrm{H}_{2} \mathrm{O}\right)\right]^{-c}$} & SAP & 3.9 \\
& TSAP & 213 \\
{$\left[\mathrm{Gd}(\mathrm{DO} 3 \mathrm{~A}-p \mathrm{HAP})\left(\mathrm{H}_{2} \mathrm{O}\right)\right]^{-}$} & SAP & 0.105 \\
& TSAP & 141 \\
\hline
\end{tabular}

${ }^{a}$ All data from ref. $120 .{ }^{b}$ Data at $\mathrm{pH}=4 .{ }^{c}$ Data at $\mathrm{pH}=9$.

(vi) Protein binding. Non-covalent binding to proteins like HSA represents an interesting strategy in improve the relaxivity of $\mathrm{Gd}^{3+}$ contrast agents and increase the time that they spend in the blood pool before excretion. ${ }^{121}$ HSA targeting was efficiently achieved with DTPA derivatives such as MS-325, which contains a lipophilic side chain that promotes protein binding. Some examples of $\mathrm{Gd}^{3+}$ (and also $\mathrm{Mn}^{2+}$ ) complexes that decrease their hydration number upon binding to HSA were reported in the literature. ${ }^{122,123}$ However, this is not the case of the $\mathrm{Gd}^{3+}$ complex with MS-325, as demonstrated by luminescence ${ }^{121}$ and ENDOR ${ }^{124}$ studies. The water exchange rate was shown to be slower when the complex was bound to human serum albumin. Aime et al. ${ }^{125}$ used ${ }^{17} \mathrm{O}$ and ${ }^{1} \mathrm{H}$ relaxometric measurements at $25{ }^{\circ} \mathrm{C}$ to determine the water exchange rates of MS-325 in its free form $\left(k_{\mathrm{ex}}^{298}=4.0 \times 10^{6} \mathrm{~s}^{-1}\right)$ and bound to HSA $\left(k_{\mathrm{ex}}^{298}=2.6 \times 10^{6} \mathrm{~s}^{-1}\right)$. Caravan $e t$ al. ${ }^{121}$ studied the system at $37{ }^{\circ} \mathrm{C}$ and reported a 3 fold decrease in exchange rate when MS-325 was bound to HSA. It was also reported that the relaxivity of MS-325 was different when bound to serum albumins from different species. ${ }^{126}$ For instance the relaxivity of MS-325 in rabbit serum albumin was much lower than that measured in HSA. By replacing Gd with $\mathrm{Dy}^{3+}$, it could be unambiguously shown that the cause of this lower relaxivity in rabbit serum albumin is an 8-fold slower water exchange rate compared to the rate measured when the complex was bound to HSA. ${ }^{127,128}$ Thus, it is clear that noncovalent binding of metal complexes with a protein may alter significantly the water exchange rate at the metal ion. 


\section{Trends across the lanthanide series}

Water exchange in aqueous solutions of $\mathrm{Ln}^{3+}$ complexes was extensively investigated for $\mathrm{Gd}^{3+}$ and $\mathrm{Eu}^{3+}$ complexes, given their relevance as $T_{1}$ and CEST agents, respectively. However, some studies also determined water exchange rates for different $\mathrm{Ln}^{3+}$ ions, so trends across the series can be analysed. The ionic radius of the $\mathrm{Ln}^{3+}$ ions experience a significant contraction across the series $(\sim 15 \%)$, ${ }^{129}$ which sometimes results in drastic changes in the properties of the corresponding complexes. For instance, a decrease of the stability of $\mathrm{Ln}^{3+}$ complexes across the series of up to seven orders of magnitude was observed when using a 18-membered crown-ether containing two picolinate pendants. ${ }^{130}$ This trend was found to be reversed for the complexes of a linear chelator containing a rigid 1,4-diazepane spacer. ${ }^{131}$

An early study on the effect of the size of the $\operatorname{Ln}^{3+}$ ion was reported for the [ $\left.\operatorname{Ln}(\mathrm{DTPA}-\mathrm{BMA})\left(\mathrm{H}_{2} \mathrm{O}\right)\right]$ complexes. ${ }^{132,133}$ The $k_{\mathrm{ex}}^{298}$ values were found to increase by one order of magnitude on decreasing the size of the $\mathrm{Ln}^{3+}$ ion from $\mathrm{Nd}^{3+}$ to $\mathrm{Ho}^{3+}$ (Table 8 ). The measured $\Delta V^{*}$ values are positive and take similar values for Eu-Ho, indicating a dissociative activated mechanism. However, the complex of the larger $\mathrm{Nd}^{3+}$ ion presents a small negative $\Delta V^{*}$, indicating an interchange mechanism. This changeover is certainly associated to a lower steric compression around the coordinated water molecule in the $\mathrm{Nd}^{3+}$ complex, which allows the entering water molecule to approach the metal ion with the outgoing water molecule leaving in a synchronous process. With respect to the one order of magnitude increase of $k_{\mathrm{ex}}^{298}$ from $\mathrm{Gd}^{3+}$ to $\mathrm{Ho}^{3+}$, this is explained by an increase of the steric compression around the coordinated water molecule, which lowers the energy of the eight-coordinate transition state with respect to the nine-coordinate ground state.

In contrast to the nine-coordinate $\left[\operatorname{Ln}(\mathrm{DTPA}-\mathrm{BMA})\left(\mathrm{H}_{2} \mathrm{O}\right)\right]$ complexes, the eight-coordinate $\left[\mathrm{Ln}(\mathrm{PDTA})\left(\mathrm{H}_{2} \mathrm{O}\right)_{2}\right]^{-}$derivatives $\left(\mathrm{PDTA}=\right.$ propylenediamine- $N, N, N^{\prime}, N^{\prime}$-tetraacetate) show a steady decrease of the water exchange rate on proceeding to the right across the series (Table 8, Fig. 13). ${ }^{134}$ The activation volumes are negative across the series from $\mathrm{Gd}^{3+}$ to $\mathrm{Tm}^{3+}$, pointing to associatively activated water exchange mechanisms. The decrease of $k_{\mathrm{ex}}^{298}$ is ascribed to a stabilization of the eight-coordinate ground state with respect to the nine-coordinate transition state as the ionic radius of the metal ion decreases. For the smallest ion, $\mathrm{Yb}^{3+}$, the activation volume is positive, which indicates that water exchange proceeds through a dissociative mechanism facilitated by a seven-coordinate transition state.

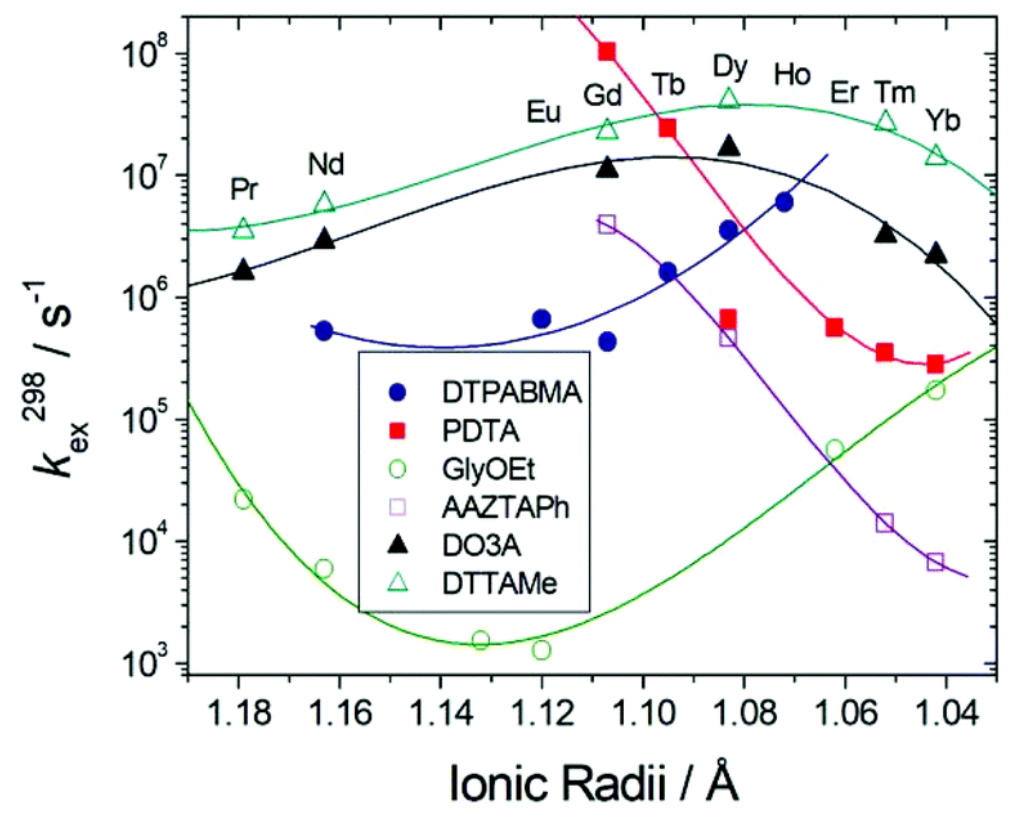

Fig. 13. Variation of $k_{\mathrm{ex}}^{298}$ across the lanthanide series for complexes with different ligands.

The solid lines represent only a guide for the eye. 
Table 8. Rate constants and activation parameters characterising water exchange for $\mathrm{Ln}^{3+}$ complexes across the series.

\begin{tabular}{|c|c|c|c|c|c|c|}
\hline Ligand & $\mathbf{L n}^{3+}$ & $k_{\mathrm{ex}}^{298} / 10^{6} \mathrm{~s}^{-1}$ & $\Delta H^{\ddagger} / \mathrm{kJ} \mathrm{mol}^{-1}$ & $\Delta S^{\ddagger} / \mathrm{J} \mathrm{mol}^{-1} \mathrm{~K}^{-1}$ & $\Delta V^{\ddagger} / \mathrm{cm}^{3} \mathrm{~mol}^{-1}$ & Ref. \\
\hline \multirow[t]{6}{*}{ DTPA-BMA } & $\mathrm{Nd}$ & 0.53 & 43.4 & +10.2 & -0.8 & 132 and 133 \\
\hline & $\mathrm{Eu}$ & 0.66 & 49.2 & +31.5 & +8.5 & \\
\hline & $\mathrm{Gd}$ & 0.43 & 46.6 & +18.9 & +7.3 & \\
\hline & $\mathrm{Tb}$ & 1.61 & 50.3 & +42.6 & +9.8 & \\
\hline & Dy & 3.53 & 48.9 & +44.4 & +7.3 & \\
\hline & Ho & 5.98 & 54.2 & +66.6 & +9.4 & \\
\hline \multirow[t]{6}{*}{ PDTA } & $\mathrm{Gd}$ & 102 & 11.0 & -54.6 & -1.5 & 134 \\
\hline & $\mathrm{Tb}$ & 24 & 9.0 & 7.6 & -7.6 & \\
\hline & Dy & 0.66 & 24.2 & -33.1 & -5.5 & \\
\hline & Er & 0.56 & 42.1 & +6.3 & -6.5 & \\
\hline & $\mathrm{Tm}$ & 0.35 & 46.0 & +15.5 & -1.2 & \\
\hline & $\mathrm{Yb}$ & 0.28 & 34.8 & -23.6 & +7.4 & \\
\hline \multirow[t]{6}{*}{ DO3A } & $\operatorname{Pr}$ & 1.6 & 23 & -50 & -0.4 & 138 \\
\hline & $\mathrm{Nd}$ & 2.9 & 40 & +12 & -0.5 & \\
\hline & $\mathrm{Gd}$ & 11 & 33.3 & +1.4 & - & \\
\hline & Dy & 16.6 & 29 & -9 & -0.5 & \\
\hline & $\mathrm{Tm}$ & 3.2 & 13 & -77 & -0.9 & \\
\hline & $\mathrm{Yb}$ & 2.2 & 12 & -83 & - & \\
\hline \multirow[t]{6}{*}{ DTTA-Me } & $\operatorname{Pr}$ & 3.5 & 26 & -31 & +7.0 & 138 \\
\hline & $\mathrm{Nd}$ & 5.8 & 49 & +49 & +6.8 & \\
\hline & $\mathrm{Gd}$ & 22.7 & 40 & +29 & +7.0 & \\
\hline & Dy & 40.6 & 36 & +21 & +1.8 & \\
\hline & $\mathrm{Tm}$ & 26.7 & 13 & -60 & +0.4 & \\
\hline & $\mathrm{Yb}$ & 13.9 & 13 & -64 & - & \\
\hline \multirow[t]{3}{*}{ AAZTAPh- $\mathrm{NO}_{2}$} & $\mathrm{Gd}$ & 3.9 & 42 & +21 & -1.4 & 139 \\
\hline & Dy & 0.46 & 36 & -15.5 & +1.9 & \\
\hline & $\mathrm{Tm}$ & 0.014 & 46 & -9.8 & -5.6 & \\
\hline
\end{tabular}

A detailed study of the water exchange kinetics in acetonitrile solution was reported for the complexes with the ethyl ester derivative of DOTAM-Gly (DOTAM-GlyOEt). ${ }^{135}$ The $k_{\mathrm{ex}}^{298}$ values decreased for the first half of the lanthanide series from $\mathrm{Pr}^{3+}$ to $\mathrm{Eu}^{3+}$, and then increased from $\mathrm{Eu}^{3+}$ to $\mathrm{Yb}^{3+}$. The exact details of the mechanisms operating across the series were not revealed due to the lack of variable-pressure data. Nevertheless, the activation entropies for this series of compounds change sign at $\mathrm{Eu}^{3+}$, suggesting a change in mechanism at this point of the series. A reasonable explanation for this trend is that the complexes of the large $\mathrm{Ln}^{3+}$ ions exchange water through an associative mechanism via a hypothetical ten-coordinate transition state. This appears to be plausible, given that a ten-coordinate $\mathrm{La}^{3+}$ complex of DOTAM was observed in the solid state. ${ }^{136}$ If this is the case, the energy cost required to reach the ten-coordinate transition state should increase from $\mathrm{Pr}^{3+}$ to $\mathrm{Eu}^{3+}$, resulting in a slower exchange. For the heaviest $\mathrm{Ln}^{3+}$ ions the mechanism is most likely dissociative, and the departure of the coordinated water molecule is facilitated as the ionic radius of the metal ion decreases (as for [ $\left.\mathrm{Ln}(\mathrm{DTPA}-\mathrm{BMA})\left(\mathrm{H}_{2} \mathrm{O}\right)\right]$ complexes). This interpretation is supported by a detailed analysis of the crystal structures of $\left[\mathrm{Ln}(\mathrm{DOTA})\left(\mathrm{H}_{2} \mathrm{O}\right)\right]^{-}$and DOTA-tetraamide complexes that revealed that the $\mathrm{Ln}-\mathrm{O}_{\text {water }}$ distance is longer for the smaller ions than anticipated according to their ionic radii, as the capping water molecule is placed in a sterically demanding position. ${ }^{137}$ 
Recently, water exchange rates and activation parameters were reported for the bis-aquated complexes $\left[\mathrm{Ln}(\mathrm{DO} 3 \mathrm{~A})\left(\mathrm{H}_{2} \mathrm{O}\right)_{2}\right]$ and $\left[\mathrm{Ln}(\mathrm{DTTA}-\mathrm{Me})\left(\mathrm{H}_{2} \mathrm{O}\right)_{2}\right]^{-}{ }^{138}$ The two series of complexes presented a similar trend in $k_{\mathrm{ex}}^{298}$ values across the series, with a maximum around $\mathrm{Dy}^{3+}\left(\right.$ Fig. 13). For the $\left[\mathrm{Ln}(\mathrm{DO} 3 \mathrm{~A})\left(\mathrm{H}_{2} \mathrm{O}\right)_{2}\right]$ complexes the $\Delta V^{\sharp}$ values remained small and nearly constant across the series, ranging from -0.4 to -0.9 $\mathrm{cm}^{3} \mathrm{~mol}^{-1}$. This is somewhat surprising considering the marked variation of the water exchange rates, suggesting an interchange mechanism throughout the series. In the case of $\left[\mathrm{Ln}(\mathrm{DTTA}-\mathrm{Me})\left(\mathrm{H}_{2} \mathrm{O}\right)_{2}\right]^{-}$the $\Delta V^{\sharp}$ values remained similar for the large $\mathrm{Ln}^{3+}$ ions $\left(\sim+7 \mathrm{~cm}^{3} \mathrm{~mol}^{-1}\right)$ dropping to $+1.8 \mathrm{~cm}^{3} \mathrm{~mol}^{-1}$ for $\mathrm{Dy}^{3+}$ and $+0.4 \mathrm{~cm}^{3} \mathrm{~mol}^{-1}$ for $\mathrm{Tm}^{3+}$. This suggests a change from a dissociative to an interchange mechanism across the series. This again seems contradictory, since there should be less space for the entering water molecule in the case of the smallest $\mathrm{Ln}^{3+}$ ions. The reasons behind this behaviour are not completely clear, but might be related to a change in complex structure across the series. For instance, the ratio of SAP/TSAP isomers in $\left[\mathrm{Ln}(\mathrm{DO} 3 \mathrm{~A})\left(\mathrm{H}_{2} \mathrm{O}\right)_{2}\right]$ may not be constant. For $\left[\mathrm{Ln}(\mathrm{DTTA}-\mathrm{Me})\left(\mathrm{H}_{2} \mathrm{O}\right)_{2}\right]^{-}$it was suggested that the observed trend might be related to a change in the relative orientation of the water molecules in the innercoordination sphere. An alternative explanation would be that the two water molecules present very different water exchange rates. The ratio of water exchange rates could vary across the lanthanide series, resulting in trends in $k_{\mathrm{ex}}^{298}$ and $\Delta V^{*}$ that reflect different contributions from the two exchanging water molecules. This explanation is supported by the observation that water molecules in capping positions experience much faster exchange (see above), and by computational studies that indicated that the two $\mathrm{Gd}-\mathrm{O}_{\text {water }}$ bonds in $\left[\mathrm{Gd}(\mathrm{DO} 3 \mathrm{~A})\left(\mathrm{H}_{2} \mathrm{O}\right)_{2}\right]$ and $\left[\mathrm{Gd}(\mathrm{DTTA}-\mathrm{Me})\left(\mathrm{H}_{2} \mathrm{O}\right)_{2}\right]^{-}$complexes differ significantly in terms of their strength. ${ }^{23,38}$

Some recent studies on $\left[\mathrm{Ln}(\mathrm{AAZTA})\left(\mathrm{H}_{2} \mathrm{O}\right)_{q}\right]^{-}$derivatives revealed marked changes in $k_{\mathrm{ex}}^{298}$ across the series associated to a change in the number of inner-sphere water molecules. ${ }^{139,140}$ The exchange rate determined for the [Gd(AAZTAPh- $\left.\left.\mathrm{NO}_{2}\right)\left(\mathrm{H}_{2} \mathrm{O}\right)_{2}\right]^{-}$complex $\left(3.9 \times 10^{6} \mathrm{~s}^{-1}\right)$ decreases by one order of magnitude to $0.46 \times$ $10^{6} \mathrm{~s}^{-1}$ for the $\mathrm{Dy}^{3+}$ analogue, which was also found to be bis-aquated. A sharp decrease of $k_{\mathrm{ex}}^{298}$ was observed on moving across the series until $\mathrm{Tm}^{3+}$, which was found to contain a single coordinated water molecule with $k_{\mathrm{ex}}^{298}=14 \times 10^{3} \mathrm{~s}^{-1}$. The change in hydration number is accompanied by a change in the sing of $\Delta V^{*}$, which takes values of +1.9 and $-5.6 \mathrm{~cm}^{3} \mathrm{~mol}^{-1}$ for the $\mathrm{Dy}^{3+}$ and $\mathrm{Tm}^{3+}$ complexes, respectively. ${ }^{139}$ Thus, a change in coordination number from nine to eight results in a changeover from a dissociative interchange to an associative mechanism, as would be expected. The monohydrated [ $\left.\mathrm{Yb}(\mathrm{AAZTA})\left(\mathrm{H}_{2} \mathrm{O}\right)\right]^{-}$complex $\left(k_{\mathrm{ex}}^{298}=\right.$ $6.67 \times 10^{3} \mathrm{~s}^{-1}$ ) presents an exchange rate even lower than the $\mathrm{Tm}^{3+}$ analogue. Thanks to this low exchange rate the signal of the bound water molecule was directly observed at $83 \mathrm{ppm}$. This coordinated water molecule provides a sizeable CEST effect, which is remarkable considering the negative charge of the complex. ${ }^{140}$

\section{Conclusions and perspectives}

Thirty years ago, water exchange at $\mathrm{Ln}^{3+}$ complexes was expected to be extremely fast. The $\mathrm{Gd}^{3+}$ aqua ion exhibits one of the fastest water exchange rates measured among the aqua ions. The experience with transition metal complexes was that the co-ligand typically had a labilizing effect on the coordinated water ligand. But for $\mathrm{Gd}^{3+}$ and other $\mathrm{Ln}^{3+}$ complexes, the presence of a co-ligand always results in reducing the exchange rate of the water ligand. This effect of the co-ligand can be quite profound and water exchange rates on $\mathrm{Ln}^{3+}$ complexes can range over 6 orders of magnitude. Coordination chemists now have ligand design frameworks that can be used to design complexes with slow or fast exchanging water ligands.

The knowledge frontiers of $\mathrm{Ln}^{3+}$ water exchange remain at the extremes. Exceedingly fast water exchange at $\mathrm{Gd}^{3+}$, e.g. $10^{9} \mathrm{~s}^{-1}$, may be useful in developing contrast agents that have high relaxivity at high fields and would be unencumbered by a long rotational correlation time. To date, ternary $\mathrm{Gd}^{3+}$ complexes have not produced a water exchange rate as fast as the aqua ion. There may be a limitation with nine-coordinate 
$\mathrm{Gd}^{3+}$ complexes that undergo water exchange through a dissociative mechanism in that as steric compression is increased to destabilize the nine-coordinate state the eight-coordinate $q=0$ intermediate eventually becomes more stable. A new class of complexes with an associative reaction mechanisms (like the aqua ion) may be required to achieve this ultrafast water exchange.

Achieving very slow water exchange rates for CEST agents is also a difficult task. Furthermore, little is known about the actual water exchange rates of $\mathrm{Ln}^{3+} \mathrm{CEST}$ candidates in vivo. For very slow exchange, environmental effects like $2^{\text {nd }}$ sphere counter ions, influence water exchange. It is likely that the $k_{\mathrm{ex}}$ values determined in vitro do not reflect accurately the actual situation in vivo. Further studies are certainly necessary to understand the difficulties in translating these paramagnetic CEST agents to in vivo studies. Besides developing new ligand structures that could aid overcoming some of the current difficulties, the use of lanthanide ions other than $\mathrm{Eu}^{3+}$ may be an interesting yet nearly unexplored alternative. Indeed, a few examples demonstrated that water exchange may vary dramatically over the lanthanide series, opening new opportunities to design complexes with particularly slow water exchange rates. Small $\mathrm{Ln}^{3+}$ ions such as $\mathrm{Tm}^{3+}$ and $\mathrm{Yb}^{3+}$ appear to be ideal candidates for this purpose due to the higher positive charge density of these cations compared to $\mathrm{Eu}^{3+}$.

While the wealth of work in inorganic reaction kinetics has produced a series of empirical guidelines to tune water exchange, on the other hand there is a certain amount of selection bias in these rules for ligand design. The majority of our experience comes from octadentate co-ligands that can be considered derivatives of DTPA or DOTA, and among those derivatives we have a good understanding of factors influencing water exchange. However a structurally different complex like $\left[\mathrm{Gd}_{3}(\mathrm{TCAS})_{2}\left(\mathrm{H}_{2} \mathrm{O}\right)_{7}\right]^{7-}$ with its extremely slow exchanging water ligands upends these rules. Similarly the labile capping bond effect makes clear that the manner in which the co-ligand binds the lanthanide, in addition to donor atom type and overall charge, can have a profound effect on water exchange kinetics. Rational design of Gd-DOTA derivatives with very fast water exchange as $T_{1}$-relaxation agents or Ln-DOTA derivatives with very slow water exchange as CEST contrast agents for MRI can nowadays be achieved. Pushing the limits of the range of exchange rates is still a challenge to coordination chemists. However more novel ligand structures are likely to yield more unpredictable exchange kinetics.

\section{Conflicts of interest}

P. C. holds equity in Collagen Medical, LLC and Reveal Pharmaceuticals, and has research funding from Pfizer, Indalo Therapeutics, and Pliant Therapeutics. The other authors declare no competing financial interest.

\section{Acknowledgements}

Authors C. P.-I. and D. E.-G. thank Ministerio de Economía y Competitividad (CTQ2016-76756-P) and Xunta de Galicia (ED431B 2017/59 and ED431D 2017/01) for generous financial support. C. P.-I. thanks Ministerio de Ciencia, Innovación y Universidades (PRX18/00201) and Fulbright for a fellowship to visit A. A. Martinos Center for Biomedical Imaging. P. C. gratefully acknowledges support from the U.S. National Institute of Biomedical Imaging and Bioengineering (R01EB009062) and the National Institute of Diabetes and Digestive and Kidney Diseases (U01DK104302). 


\section{References}

01 (a) L. Helm and A. E. Merbach, Chem. Rev., 2005, 105, 1923; (b) L. Helm and A. E. Merbach, Coord. Chem. Rev., 1999, 187, 151; (c) T. Kowall, P. Caravan, H. Bourgeois, L. Helm, F. P. Rotzinger and A. E. Merbach, J. Am. Chem. Soc., 1998, 120, 6569.

02 (a) W. H. Casey and T. W. Swaddle, Rev. Geophys., 2003, 41, 1008; (b) A. Brausam and R. van Eldik, in Advances in Inorganic Chemistry, ed. R. van Eldik and I. Ivanovic-Burmazovic, Academic Press, 2012, ch. 5, vol. 64, pp. 141-181.

03 A. Cusanelli, U. Frey, D. T. Richens and A. E. Merbach, J. Am. Chem. Soc., 1996, 118, 5265.

04 (a) P. Caravan, E. Toth, A. Rockenbauer and A. E. Merbach, J. Am. Chem. Soc., 1999, 121, 10403; (b) G. Moreau, L. Helm, J. Purans and A. E. Merbach, J. Phys. Chem. A, 2002, 106, 3034.

05 (a) D. T. Richens, Chem. Rev., 2005, 105, 1961; (b) L. Helm, J. R. Morrow, C. J. Bond, F. Carniato, M. Botta, M. Braun, Z. Baranyai, R. Pujales-Paradela, M. Regueiro-Figueroa, D. Esteban-Gomez, C. Platas-Iglesias and T. J. Scholl., Gadolinium-based Contrast Agents, in Contrast Agents for MRI: Experimental Methods, ed. V. C. Pierre and M. J. Allen, RSC, 2018, ch. 2, pp. 121-242.

06 (a) A. E. Merbach, Pure Appl. Chem., 1987, 59, 161; (b) M. Kotowski and R. van Eldik, Coord. Chem. Rev., 1989, 93, 19; (c) C. D. Hubbard and R. van Eldik, Inorg. Chim. Acta, 2010, 363, 2357.

07 T. W. Swaddle, Adv. Inorg. Bioinorg. Mech., 1983, $2,95$.

08 (a) D. H. Powell and A. E. Merbach, Magn. Reson. Chem., 1994, 32, 739; (b) C. Cossy, L. Helm and A. E. Merbach, Inorg. Chem., 1989, 28, 2699; (c) C. Cossy, L. Helm and A. E. Merbach, Inorg. Chem., 1988, 27, 1973.

09 (a) D. Hao, T. Ai, F. Goerner, X. Hu, V. M. Runge and M. Tweedle, J. Magn. Reson. Imaging, 2012, 36, 1060; (b) J. Wahsner, E. M. Gale, A. Rodriguez-Rodriguez and P. Caravan, Chem. Rev., 2019, 119, 957; (c) P. Caravan, J. J. Ellison, T. J. McMurry and R. B. Lauffer, Chem. Rev., 1999, 99, 2293; (d) M. C. Heffem, L. M. Matosziuk and T. J. Meade, Chem. Rev., 2013, 114, 4496.

10 E. Toth, L. Helm and A. Merbach, Relaxivity of Gadolinium(III) Complexes: Theory and Mechanism, in The Chemistry of Contrast Agents in Medical Magnetic Resonance Imaging, ed. A. Merbach, L. Helm and E. Toth, John Wiley \& Sons, Ltd., 2013, ch. 2, pp. 21-85.

11 (a) P. Caravan, Chem. Soc. Rev., 2006, 35, 512; (b) B. N. Siriwardena-Mahanama and M. J. Allen, Molecules, 2013, 18, 9352.

12 (a) L. Helm, Future Med. Chem., 2010, 2, 385; (b) P. Caravan, C. T. Farrar, L. Frullano and R. Uppal, Contrast Media Mol. Imaging, 2009, 4, 89.

13 (a) I. Hancu, W. T. Dixon, M. Woods, E. Vinogradov, A. D. Sherry and R. E. Lenkinski, Acta Radiol., 2010, 51, 910; (b) E. Vinogradov, A. D. Sherry and R. E. Lenkinski, J. Magn. Reson., 2013, 229, 155; (c) M. Woods, D. E. Woessner and A. D. Sherry, Chem. Soc. Rev., 2006, 35, 500 .

14 (a) S. Zhang, L. Michaudet, S. Burgess and A. D. Sherry, Angew. Chem., Int. Ed., 2002, 41, 1919; (b) S. Viswanathan, S. J. Ratnakar, K. N. Green, Z. Kovacs, L. M. De Leon-Rodriguez and A. D. Sherry, Angew. Chem., Int. Ed., 2009, 48, 9330.

15 (a) G. Castro, M. Regueiro-Figueroa, D. Esteban-Gomez, R. Bastida, A. Macias, P. Perez-Lourido, C. Platas-Iglesias and L. Valencia, Chem. - Eur. J., 2015, 21, 18662; (b) C.-H. Huang and J. R. Morrow, 
J. Am. Chem. Soc., 2009, 131, 4206; (c) G. Ferrauto, F. Beauprez, E. Di Gregorio, C. Carrera, S. Aime, E. Terreno and D. Delli Castelli, Dalton Trans., 2019, 48, 5343; (d) D. Delli Castelli, E. Terreno and S. Aime, Angew. Chem., Int. Ed., 2011, 50, 1798.

16 (a) T. Chauvin, P. Durand, M. Bernier, H. Meudal, B.-T. Doan, F. Noury, B. Badet, J.-C. Beloeil and E. Toth, Angew. Chem., Int. Ed., 2008, 47, 4370; (b) G. Liu, Y. Li and M. D. Pagel, Magn. Reson. Med., 2007, 58, 1249.

17 S. Zhang, M. Merritt, D. E. Woessner, R. E. Lenkinski and A. D. Sherry, Acc. Chem. Res., 2003, 36, 783.

18 A. D. Sherry and Y. Wu, Curr. Opin. Chem. Biol., 2013, 17, 167.

19 S. A. Cotton, C. R. Chim., 2005, 8, 129.

20 (a) L. Valencia, J. Martinez, A. Macías, R. Bastida, R. A. Carvalho and C. F. G. C. Geraldes, Inorg. Chem., 2002, 41, 5300; (b) M. de C. Fernandez-Fernandez, R. Bastida, A. Macias, P. Perez-Lourido, C. Platas-Iglesias and L. Valencia, Inorg. Chem., 2006, 45, 4484; (c) G. Castro, M. RegueiroFigueroa, D. Esteban-Gomez, P. Perez-Lourido, C. Platas-Iglesias and L. Valencia, Inorg. Chem., 2016, 55, 3490; (d) A. Nonat, D. Esteban-Gomez, L. Valencia, P. Perez-Lourido, J. L. Barriada, L. J. Charbonniere and C. Platas-Iglesias, Dalton Trans., 2019, 48, 4035.

21 D. H. Powell, O. M. Ni Dhubhghaill, D. Pubanz, L. Helm, Y. S. Lebedev, W. Schlaepfer and A. E. Merbach, J. Am. Chem. Soc., 1996, 118, 9333.

22 H. Lammers, F. Maton, D. Pubanz, M. W. van Laren, H. van Bekkum, A. E. Merbach, R. R. Muller and J. A. Peters, Inorg. Chem., 1997, 36, 2527.

23 S. Karimi, G. Hunter, L. Moriggi, C. Platas-Iglesias and L. Helm, Inorg. Chem., 2016, 55, 6231.

24 S. Aime, A. Barge, A. Borel, M. Botta, S. Chemerisov, A. E. Merbach, U. Müller and D. Pubanz, Inorg. Chem., 1997, 36, 5104.

K. Micskei, D. H. Powell, L. Helm, E. Brucher and A. E. Merbach, Magn. Reson. Chem., 1993, 31, 1011.

26 M. K. Thompson, M. Botta, G. Nicolle, L. Helm, S. Aime, A. E. Merbach and K. N. Raymond, J. Am. Chem. Soc., 2003, 125, 14274.

E. J. Werner, A. Datta, C. J. Jocher and K. N. Raymond, Angew. Chem., Int. Ed., 2008, 47, 8568.

28 E. Toth, L. Helm, A. E. Merbach, R. Hedinger, K. Hegetschweiler and A. Janossy, Inorg. Chem., 1998, 37, 4104.

29 L. Burai, E. Toth, H. Barzin, M. Benmelouka, Z. Jaszberenyi, L. Helm and A. E. Merbach, Dalton Trans., 2006, 629.

30 Z. Palinkas, A. Roca-Sabio, M. Mato-Iglesias, D. Esteban-Gomez, C. Platas-Iglesias, A. de Blas, T. Rodríguez-Blas and E. Tóth, Inorg. Chem., 2009, 48, 8878.

31 M. Mato-Iglesias, A. Roca-Sabio, Z. Palinkas, D. Esteban-Gómez, C. Platas-Iglesias, E. Tóth, A. de Blas and T. Rodríguez-Blas, Inorg. Chem., 2008, 47, 7840.

32 S. Aime, A. Barge, J. I. Bruice, M. Botta, J. A. K. Howard, J. M. Moloney, D. Parker, A. S. de Sousa and M. Woods, J. Am. Chem. Soc., 1999, 121, 5762. 
W. S. Fernando, A. F. Martins, P. Zhao, Y. Wu, G. E. Kiefer, C. Platas-Iglesias and A. D. Sherry, Inorg. Chem., 2016, 55, 3007.

34 (a) A. Beeby, I. M. Clarkson, R. S. Dickins, S. Faulkner, D. Parker, L. Royle, A. S. de Sousa, J. A. G. Williams and M. Woods, J. Chem. Soc., Perkin Trans. 2, 1999, 493-503; (b) R. M. Supkowski and W. D. Horrocks Jr., Inorg. Chim. Acta, 2002, 340, 44-48.

35 E. Toth, L. Burai, E. Brücher and A. E. Merbach, J. Chem. Soc., Dalton Trans., 1997, 1587.

36 E. Toth, D. Pubanz, S. Vauthey, L. Helm and A. E. Merbach, Chem. - Eur. J., 1996, 2, 1607.

37 R. Pujales-Paradela, T. Savic, D. Esteban-Gómez, G. Angelovski, F. Carniato, M. Botta and C. PlatasIglesias, Chem. - Eur. J., 2019, 25, 4782.

M. Regueiro-Figueroa and C. Platas-Iglesias, J. Phys. Chem. A, 2015, 119, 6436.

(a) S. Aime, M. Botta, M. Fasano, M. P. M. Marques, C. F. G. C. Geraldes, D. Pubanz and A. E. Merbach, Inorg. Chem., 1997, 36, 2059; (b) S. Aime, A. Barge, F. Benetollo, G. Bombieri, M. Botta and F. Uggeri, Inorg. Chem., 1997, 36, 4287; (c) S. Aime, M. Botta and G. Ermondi, Inorg. Chem., 1992, 31, 4291.

40 (a) D. Parker, R. S. Dickins, H. Puschmann, C. Crossland and J. A. K. Howard, Chem. Rev., 2002, 102, 1977; (b) C. Platas-Iglesias, Eur. J. Inorg. Chem., 2012, 2023; (c) M. Purgel, Z. Baranyai, A. de Blas, T. Rodriguez-Blas, I. Banyai, C. Platas-Iglesias and I. Toth, Inorg. Chem., 2010, 49, 4370; (d) P. Hermann, J. Kotek, V. Kubicak and I. Lukes, Dalton Trans., 2008, 3027.

S. Aime, A. Barge, M. Botta, A. S. De Sousa and D. Parker, Angew. Chem., Int. Ed., 1998, 37, 2673.

F. A. Dunand, S. Aime and A. E. Merbach, J. Am. Chem. Soc., 2000, 122, 1506.

F. A. Dunand, R. S. Dickins, D. Parker and A. E. Merbach, Chem. - Eur. J., 2001, 7, 5160.

S. Zhang, K. Wu, M. C. Biewer and A. D. Sherry, Inorg. Chem., 2001, 40, 4284.

S. Zhang, P. Winter, K. Wu and A. D. Sherry, J. Am. Chem. Soc., 2001, 123, 1517.

S. Viswanathan, Z. Kovac, K. N. Green, S. J. Ratnakar and A. D. Sherry, Chem. Rev., 2010, 110, 2960.

S. Aime, M. Botta, Z. Garda, B. E. Kucera, G. Tircso, V. G. Young and M. Woods, Inorg. Chem., 2011, 50, 7955.

M. Woods, M. Botta, S. Avedano, J. Wang and A. D. Sherry, Dalton Trans., 2005, 3829.

49 M. Woods, A. Pasha, P. Zhao, G. Tircso, S. Chowdhury, G. Kiefer, D. E. Woessner and A. D. Sherry, Dalton Trans., 2011, 40, 6759.

50 D. Delli Castelli, M. C. Caligara, M. Botta, E. Terreno and S. Aime, Inorg. Chem., 2013, 52, 7130.

51 C. Kumas, W. S. Fernando, P. Zhao, M. Regueiro-Figueroa, G. E. Kiefer, A. F. Martins, C. PlatasIglesias and A. D. Sherry, Inorg. Chem., 2016, 55, 9297.

52 (a) M. Woods, Z. Kovacs, S. Zhang and A. D. Sherry, Angew. Chem., Int. Ed., 2003, 42, 5889; (b) S. Avedano, M. Botta, J. S. Haigh, D. L. Longo and M. Woods, Inorg. Chem., 2013, 52, 8436; (c) G. Tircso, B. C. Webber, B. E. Kucera, V. G. Young and M. Woods, Inorg. Chem., 2011, 50, 7966. 
53 (a) P. Caravan, G. Parigi, J. M. Chasse, N. J. Cloutier, J. J. Ellison, R. B. Lauffer, C. Luchinat, S. A. McDermid, M. Spiller and T. J. McMurry, Inorg. Chem., 2007, 46, 6632; (b) Z. Tyeklar, S. U. Dunham, K. Midelfort, D. M. Scott, H. Sajiki, K. Ong, R. B. Lauffer, P. Caravan and T. J. McMurry, Inorg. Chem., 2007, 46, 6621.

54 L. Burai, E. Toth, A. Sour and A. E. Merbach, Inorg. Chem., 2005, 44, 3561.

55 R. Ruloff, E. Toth, R. Scopelliti, R. Tripier, H. Handel and A. E. Merbach, Chem. Commun., 2002, 2, 2630.

56 J.-G. Kang, M.-K. Na, S.-K. Yoon, Y. Sohn, Y.-D. Kim and I.-H. Suh, Inorg. Chim. Acta, 2000, 310, 56.

S. Laus, R. Ruloff, E. Toth and A. E. Merbach, Chem. - Eur. J., 2003, 9, 3555.

H.-H. Chang, C.-Y. Chen, G. Singh, H.-Y. Chen, G.-C. Liu, Y.-G. Goan, S. Aime and Y.-M. Wang, Inorg. Chem., 2011, 50, 1275.

Y.-M. Wang, C.-R. Li, Y.-C. Huang, M.-H. Ou and G.-C. Liu, Inorg. Chem., 2005, 44, 382.

60 Z. Jaszberenyi, A. Sour, E. Toth, M. Benmelouka and A. E. Merbach, Dalton Trans., 2005, 2713.

61 (a) L. Tei, Z. Baranyai, L. Gaino, A. Forgacs, A. Vagner and M. Botta, Dalton Trans., 2015, 44, 5467;

(b) A. Congreve, D. Parker, E. Gianolio and M. Botta, Dalton Trans., 2004, 1441.

A. Nonat, M. Giraud, C. Gateau, P. H. Fries, L. Helm and M. Mazzanti, Dalton Trans., 2009, 8033.

J. Kotek, P. Lebduskova, P. Hermann, L. Vander Elst, R. N. Muller, C. F. G. C. Geraldes, T. Maschmeyer, I. Lukes and J. A. Peters, Chem. - Eur. J., 2003, 9, 5899.

L. Tei, M. Botta, C. Lovazzano, A. Barge, L. Milone and S. Aime, Magn. Reson. Chem., 2008, 46, S86.

(a) J. Rudovsky, P. Cigler, J. Kotek, P. Hermann, P. Vojtisek, I. Lukes, J. A. Peters, L. Vander Elst and R. N. Muller, Chem. - Eur. J., 2005, 11, 2373; (b) P. Lebduskova, P. Hermann, L. Helm, E. Toth, J. Kotek, K. Binnemans, J. Rudovsky, I. Lukes and A. E. Merbach, Dalton Trans., 2007, 493; (c) J. Rudovsky, J. Kotek, P. Hermann, I. Lukes, V. Mainero and S. Aime, Org. Biomol. Chem., 2005, 3, 112.

66 M. Polasek, M. Sedinova, J. Kotek, L. Vander Elst, R. N. Muller, P. Hermann and I. Lukes, Inorg. Chem., 2009, 48, 455.

67 (a) M. Purgel, Z. Baranyai, A. de Blas, T. Rodríguez-Blas, I. Banyai, C. Platas-Iglesias and I. Toth, Inorg. Chem., 2010, 49, 4370; (b) Z. Kotkova, G. A. Pereira, K. Djanashvili, J. Kotek, J. Rudovsky, P. Hermann, L. Vander Elst, R. N. Muller, C. F. G. C. Geraldes, I. Lukes and J. A. Peters, Eur. J. Inorg. Chem., 2009, 119; (c) M. P. C. Campello, S. Lacerda, I. C. Santos, G. A. Pereira, C. F. G. C. Geraldes, J. Kotek, P. Hermann, J. Vanek, P. Lubal, V. Kubicek, E. Toth and I. Santos, Chem. - Eur. J., 2010, 16, 8446; (d) F. Avecilla, J. A. Peters and C. F. G. C. Geraldes, Eur. J. Inorg. Chem., 2003, 4179; (e) M. P. Campello, M. Balbina, I. Santos, P. Lubal, R. Sevcik and R. Sevcikova, Helv. Chim. Acta, 2009, 92, 2398; (f) F. K. Kalman, Z. Baranyai, I. Toth, I. Banyai, R. Kiraly, E. Brucher, S. Aime, X. Sun, A. D. Sherry and Z. Kovacs, Inorg. Chem., 2008, 47, 3851.

68 S. Aime, M. Botta, S. Geninatti-Crich, G. Giovenzana, R. Pagliarin, M. Sisti and E. Terreno, Magn. Reson. Chem., 1998, 36, S200. 

and M. Sisti, J. Med. Chem., 2000, 43, 4017.

70 S. Aime, E. Gianolio, D. Corpillo, C. Cavallotti, G. Palmisano, M. Sisti and G. B. Giovenzana, Helv. Chim. Acta, 2003, 86, 615.

71 A. Nonat, C. Gateau, P. H. Fries and M. Mazzanti, Chem. - Eur. J., 2006, 12, 7133.

72 C. Platas-Iglesias, M. Mato-Iglesias, K. Djanashvili, R. N. Muller, L. Vander Elst, J. A. Peters, A. de Blas and T. Rodríguez-Blas, Chem. - Eur. J., 2004, 13, 3579.

73 (a) M. Mato-Iglesias, C. Platas-Iglesias, K. Djanashvili, J. A. Peters, E. Toth, E. Balogh, R. N. Muller, L. Vander Elst, A. de Blas and T. Rodriguez-Blas, Chem. Commun., 2005, 4729; (b) E. Balogh, M. Mato-Iglesias, C. Platas-Iglesias, E. Toth, K. Djanashvili, J. A. Peters, A. de Blas and T. RodriguezBlas, Inorg. Chem., 2006, 45, 8719.

74 (a) A. Rodriguez-Rodriguez, D. Esteban-Gomez, A. de Blas, T. Rodriguez-Blas, M. Fekete, M. Botta, R. Tripier and C. Platas-Iglesias, Inorg. Chem., 2012, 51, 2109; (b) A. Rodriguez-Rodriguez, Z. Garda, E. Ruscsak, D. Esteban-Gomez, A. de Blas, T. Rodriguez-Blas, L. M. P. Lima, M. Beyler, R. Tripier, G. Tircso and C. Platas-Iglesias, Dalton Trans., 2015, 44, 5017.

75 S. Dumas, V. Jacques, W.-C. Sun, J. S. Troughton, J. T. Welch, J. M. Chasse, H. Schmitt-Willich and P. Caravan, Invest. Radiol., 2010, 45, 600.

76 V. Jacques, S. Dumas, W.-C. Sun, J. S. Troughton, M. T. Greenfield and P. Caravan, Invest. Radiol., $2010,45,613$.

77 M. F. Ferreira, A. F. Martins, J. A. Martins, P. M. Ferreira, E. Toth and C. F. G. C. Geraldes, Chem. Commun., 2009, 6475.

78 E. Boros, M. Polasek, Z. Zhang and P. Caravan, J. Am. Chem. Soc., 2012, 134, 19858.

79 E. Boros and P. Caravan, J. Med. Chem., 2013, 56, 1782.

80 E. Boros, S. Karimi, N. Kenton, L. Helm and P. Caravan, Inorg. Chem., 2014, 53, 6985.

81 G. Ferrauto, D. Delli Castelli, L. Leone, M. Botta, S. Aime, Z. Baranyai and L. Tei, Chem. - Eur. J., 2019, 25, 4184.

82 M. Botta, S. Avedano, G. B. Giovenzana, A. Lombardi, D. Longo, C. Cassino, L. Tei and S. Aime, Eur. J. Inorg. Chem., 2011, 802.

83 E. M. Gale, N. Kenton and P. Caravan, Chem. Commun., 2013, 49, 8060.

84 E. Boros and P. Caravan, Inorg. Chem., 2015, 54, 2403.

85 (a) J. B. Livramento, L. Helm, A. Sour, C. O'Neil, A. E. Merbach and E. Toth, Dalton Trans., 2008, 1195; (b) J. B. Livramento, A. Sour, A. Borel, A. E. Merbach and E. Toth, Chem. - Eur. J., 2006, 12, 989.

86 L. Pellegatti, J. Zhang, B. Drahos, S. Villette, F. Suzenet, G. Guillaumet, S. Petoud and E. Toth, Chem. Commun., 2008, 6591.

87 (a) C. S. Bonnet, F. Buron, F. Caille, C. M. Shade, B. Drahos, L. Pellegatti, J. Zhang, S. Villette, L. Helm, C. Pichon, F. Suzenet, S. Petoud and E. Toth, Chem. - Eur. J., 2012, 18, 1419; (b) F. Caille, C. 
S. Bonnet, F. Buron, S. Villette, L. Helm, S. Petoud, F. Suzenet and E. Toth, Inorg. Chem., 2012, 51, 2522.

88 E. Toth, O. M. Ni Dhubhghaill, G. Besson, L. Helm and A. E. Merbach, Magn. Reson. Chem., 1999, 37, 701.

Z. Baranyai, L. Tei, G. B. Giovenzana, F. K. Halman and M. Botta, Inorg. Chem., 2012, 51, 2597.

90

P. Caravan, J. C. Amedio Jr., S. U. Dunham, M. T. Greenfield, N. J. Cloutier, S. A. McDermid, M. Spiller, S. G. Zech, R. J. Looby, A. M. Raitsimring, T. J. McMurry and R. B. Lauffer, Chem. - Eur. J., $2005, \mathbf{1 1}, 5866$.

N. Iki, E. Boros, M. Nakamura, R. Baba and P. Caravan, Inorg. Chem., 2016, 55, 4000.

A. Vagner, E. Gianolio, S. Aime, A. Maiocchi, I. Toth, Z. Baranyai and L. Tei, Chem. Commun., 2016, 52, 11235.

93 S. Aime, L. Calabi, C. Cavallotti, E. Gianolio, G. B. Giovenzana, P. Losi, A. Maiocchi, G. Palmisano and M. Sisti, Inorg. Chem., 2004, 43, 7588.

94 (a) Z. Baranyai, M. Botta, M. Fekete, G. B. Giovenzana, R. Negri, L. Tei and C. Platas-Iglesias, Chem. - Eur. J., 2012, 18, 7680; (b) R. Negri, Z. Baranyai, L. Tei, G. B. Giovenzana, C. PlatasIglesias, A. C. Benyei, J. Bodnar, A. Vagner and M. Botta, Inorg. Chem., 2014, 53, 12499.

Z. Baranyai, L. Tei, G. B. Giovenzana, F. K. Kalman and M. Botta, Inorg. Chem., 2012, 51, 2597.

96 C. S. Bonnet, S. Laine, F. Buron, G. Tircso, A. Pallier, L. Helm, F. Suzenet and E. Toth, Inorg. Chem., 2015, 54, 5991.

97 A. Rodriguez-Rodriguez, M. Regueiro-Figueroa, D. Esteban-Gomez, T. Rodriguez-Blas, V. Patinec, R. Tripier, G. Tircso, F. Carniato, M. Botta and C. Platas-Iglesias, Chem. - Eur. J., 2017, 23, 1110.

M. Polasek and P. Caravan, Inorg. Chem., 2013, 52, 4084.

M. Le Fur, E. Molnar, M. Beyler, F. K. Kalman, O. Fougere, D. Esteban-Gomez, O. Rousseaux, R. Tripier, G. Tircso and C. Platas-Iglesias, Chem. - Eur. J., 2018, 24, 3127.

K. M. Payne, J. M. Wilds, F. Carniato, M. Botta and M. Woods, Isr. J. Chem., 2017, 57, 880.

101 (a) A. L. Thompson, D. Parker, D. A. Fulton, J. A. K. Howard, S. U. Pandya, H. Puschmann, K. Senanayake, P. A. Stenson, A. Badari, M. Botta, S. Avedano and S. Aime, Dalton Trans., 2006, 5605; (b) A. Barge, M. Botta, D. Parker and H. Puschmann, Chem. Commun., 2003, 1386.

S. Zhang, X. Jiang and A. D. Sherry, Helv. Chim. Acta, 2005, 88, 923.

G. Bombieri, N. Marchini, S. Ciattini, A. Mortillaro and S. Aime, Inorg. Chim. Acta, 2006, 359, 3405.

N. Cakic, B. Tickner, M. Zaiss, D. Esteban-Gomez, C. Platas-Iglesias and G. Angelovski, Inorg. Chem., 2017, 56, 7737.

O. M. Evbuomwan, J. Lee, M. Woods and A. D. Sherry, Inorg. Chem., 2014, 53, 10012.

S. Aime, A. Barge, M. Botta, D. Parker and A. S. De Sousa, J. Am. Chem. Soc., 1997, 119, 4767. 
L. Zhang, A. F. Martins, P. Zhao, Y. Wu, G. Tircso and A. D. Sherry, Angew. Chem., Int. Ed., 2017, 56, 16626.

109 L. Zhang, O. M. Evbuomwan, M. Tieu, P. Zhao, A. F. Martins and A. D. Sherry, Philos. Trans. R. Soc. London, Ser. A, 2017, 375, 20170113.

110 S. J. Ratnakar, S. Viswanathan, Z. Kovacs, A. K. Jindal, K. N. Green and A. D. Sherry, J. Am. Chem. Soc., 2012, 134, 5798.

111 S. Aime, A. Barge, A. S. Batsanov, M. Botta, D. Delli Castelli, F. Fedeli, A. Mortillaro, D. Parker and H. Puschmann, Chem. Commun., 2002, 1120.

112 T. Mani, G. Tircso, O. Togao, P. Zhao, T. C. Soesbe, M. Takahashi and A. D. Sherry, Contrast Media Mol. Imaging, 2009, 4, 183.

113 J. Singh, V. Rustagi, S. Zhang, A. D. Sherry and G. Udugamasooriya, Magn. Reson. Chem., 2017, 55, 747.

114 O. M. Evbuomwan, G. Kiefer and A. D. Sherry, Eur. J. Inorg. Chem., 2012, 2126.

115 D. M. Doble, M. Botta, J. Wang, S. Aime, A. Barge and K. N. Raymond, J. Am. Chem. Soc., 2001, 123, 10758.

116 B. N. Siriwardena-Mahanama and M. J. Allen, Dalton Trans., 2013, 42, 6724.

117 S. J. Ratnakar, M. Woods, A. J. M. Lubag, Z. Kovacs and A. D. Sherry, J. Am. Chem. Soc., 2008, 130, 6.

118 S. Viswanathan, S. J. Ratnakar, K. N. Green, Z. Kovacs, L. M. De Leon-Rodriguez and A. D. Sherry, Angew. Chem., Int. Ed., 2009, 48, 9330.

119 T. Mani, A. C. L. Opina, P. Zhao, O. M. Evbuomwan, N. Milburn, G. Tircso, C. Kumas and A. D. Sherry, J. Biol. Inorg. Chem., 2014, 19, 161.

120 L. Leone, D. Esteban-Gómez, C. Platas-Iglesias, M. Milanesio and L. Tei, Chem. Commun., 2019, 55, 513.

121 P. Caravan, N. J. Cloutier, M. T. Greenfield, S. A. McDermid, S. U. Dunham, J. W. M. Bulte, J. C. Amedio Jr., R. J. Looby, R. M. Supkowski, W. DeW. Horrocks Jr., T. J. McMurry and R. B. Lauffer, J. Am. Chem. Soc., 2002, 124, 3152.

122 S. Aime, E. Gianolio, E. Terreno, G. B. Giovenzana, R. Pagliarin, M. Sisti, G. Palmisano, M. Botta, M. P. Lowe and D. Parker, J. Biol. Inorg. Chem., 2000, 5, 488-497.

123 M. Regueiro-Figueroa, G. A. Rolla, D. Esteban-Gómez, A. de Blas, T. Rodríguez-Blas, M. Botta and C. Platas-Iglesias, Chem. - Eur. J., 2014, 20, 17300.

124 S. G. Zech, W.-C. Sun, V. Jacques, P. Caravan, A. V. Astashkin and A. M. Raitsimring, ChemPhysChem, 2005, 6, 2570.

125 S. Aime, M. Chiaussa, G. Digilio, E. Gianolio and E. Terreno, J. Biol. Inorg. Chem., 1999, 4, 766.

126 H. B. Eldredge, M. Spiller, J. M. Chasse, M. T. Greenfield and P. Caravan, Invest. Radiol., 2006, 41, 229. 
P. Caravan, M. T. Greenfield and J. W. M. Bulte, Magn. Reson. Med., 2001, 46, 917.

128 S. G. Zech, H. B. Eldredge, M. P. Lowe and P. Caravan, Inorg. Chem., 2007, 46, 3576.

129 R. D. Shannon, Acta Crystallogr., Sect. A: Cryst. Phys., Diffr., Theor. Gen. Crystallogr., 1976, 32, 751.

130 A. Roca-Sabio, M. Mato-Iglesias, D. Esteban-Gómez, E. Toth, A. de Blas, C. Platas-Iglesias and T. Rodríguez-Blas, J. Am. Chem. Soc., 2009, 131, 3331.

131 L. Tei, Z. Baranyai, E. Brucher, C. Cassino, F. Demicheli, N. Masciocchi, G. B. Giovenzana and M. Botta, Inorg. Chem., 2010, 49, 616-625.

132 D. Pubanz, G. Gonzalez, D. H. Powell and A. E. Merbach, Inorg. Chem., 1995, 34, 4447.

133 G. Gonzalez, D. H. Powell, V. Tissieres and A. E. Merbach, J. Phys. Chem., 1994, 98, 53.

134 N. Graeppi, D. H. Powell, G. Laurenczy, L. Zekany and A. E. Merbach, Inorg. Chim. Acta, 1995, 235, 311.

135 S. Zhang, K. Wu and A. D. Sherry, J. Am. Chem. Soc., 2002, 124, 4226.

136 S. Amin, J. R. Morrow, C. H. Lake and M. R. Churchill, Angew. Chem., Int. Ed. Engl., 1994, 33, 773.

137 D. Parker, H. Puschmann, A. S. Batsanov and K. Senanayake, Inorg. Chem., 2003, 42, 8646.

138 S. Karimi and L. Helm, Inorg. Chem., 2016, 55, 4555.

139 S. Karimi, L. Tei, M. Botta and L. Helm, Inorg. Chem., 2016, 55, 6300.

140 D. Delli Castelli, L. Tei, F. Carniato, S. Aime and M. Botta, Chem. Commun., 2018, 54, 2004. 